\title{
A Highly Efficient Pinacol Coupling Approach to Trehazolamine Starting from D-Glucose
}

\author{
I sabel Storch de Gracia, Hansjörg Dietrich, Sofía Bobo, and J ose Luis Chiara* \\ Instituto de Química Orgánica General, CSIC, J uan de la Cierva, 3, E-28006 Madrid, Spain \\ Received May 5, 1998
}

\begin{abstract}
A short and very efficient synthesis of trehazolamine (3), the aglycon of the potent trehalase inhibitor trehazol in (2), has been achieved starting from D-glucose. The key transformation in this approach is a high-yielding two-step, one-pot sequence consisting of a Swern oxidation of a 1,5-diol followed by a reductive carbocyclization of the resultant 1,5-dicarbonyl compound promoted by samarium diiodide. The overall yield of $\mathbf{3}$ is 39\% over nine steps from 2,3,4,6-tetra-O-benzyl-D-glucose (5). An even shorter synthesis of $\mathbf{3 0}$, a diastereoisomeric analogue of $\mathbf{3}$, is al so described starting from 5. The key transformation in this second route is a highly stereoselective ketone oxime ether reductive carbocyclization promoted also by samarium diiodide. The overall yield of $\mathbf{3 0}$ is $57 \%$ over four steps from $\mathbf{5}$.
\end{abstract}

\section{Introduction}

Trehalase is an enzyme that specifically hydrolyses $\alpha, \alpha$-trehalose (1, Figure 1$)$ to its two glucose units and is widely distributed in microorganisms, insects, plants, and animals. Trehalose is ubiquitously found in insects, being their principal blood sugar and used to support various energy-requiring functions, such as insect flight. ${ }^{1}$ Trehal ose and trehalase have been reported to participate also in germination of ascospores in fungi ${ }^{2}$ and in glucose transport in mammalian kidney or intestine. ${ }^{3}$ The development of specific and potent trehalase inhibitors is, therefore, of great interest for the control of insects and certain fungi. One such inhibitor, trehazol in (2), was isolated in 1991 from the culture broth of Micromonospora strain sp. SANK $62390^{4}$ and from Amycolatopsis trehal ostatica. ${ }^{5}$ Its peculiar structure, a pseudodisaccharide consisting of an $\alpha$-D-glucopyranose moiety bonded to a unique aminocyclopentitol (trehazolamine, 3) through a cyclic isourea group, was confirmed through synthetic studies $^{6-9}$ that also allowed establishment of its absolute

* Corresponding author. Phone: +34-915622900. Fax: +34 915644853. E-mail: iqolc22@fresno.csic.es.

(1) (a) Clegg, J . S.; Evans, D. R. J . Exp. Biol. 1961, 38, 771. (b) Sacktor, B. S.; Wormser-Shavit, E. J . Biol. Chem. 1966, 241, 634.

(2) (a) Hecker, L. I.; Sussman, A. S. J . Bacteriol . 1973, 115, 592. (b) I noue, I.; Shimoda, C. Mol. Gen. Gent. 1981, 183, 32. (c) Thevelein, J. M.; den-Hollander, J. A.; Shulman, R. G. Proc. Natl. Acad. Sci. 1982, 79, 3503. (d) Thevelein, J. M.; J ones, K. A. Eur. J . Biochem. 1983, 136, 583.

(3) Sacktor, B. Proc. Natl. Acad. Sci. 1968, 60, 1007.

(4) (a) Ando, O.; Satake, H.; Itoi, K.; Sato, A.; Nakajima, M. Takahashi, S.; Haruyama, H. J . Antibiot. 1991, 44, 1165. (b) Ando, O.; Nakajima, M.; Hamano, K.; I toi, K.; Takahashi, S.; Takamatsu, Y.; Sato, A.; Enokita, R.; Haruyama, H.; Kinoshita, T.J . Antibiot. 1993, $46,1116$.

(5) Nakayama, T.; Amachi, T.; Murao, S.; Sakai, T.; Shin, T.; Kenny, P. T. M.; I washita, T.; Zagorski, M.; Komura, H.; N omoto, K.J . Chem. Soc., Chem. Commun. 1991, 919. I nitially, the structure of the inhibitor isolated from this broth was wrongly assigned as 5-epi-trehazolin, named trehalostatin.

(6) (a) Ogawa, S.; Ushida, C.; Yuming, Y. J . Chem. Soc., Chem. Commun. 1992, 886. (b) Ogawa, S.; Ushida, C. J. Chem. Soc., Perkin Trans. 1 1992, 1939. (c) Ogawa, S.; Uchida, C. Chem. Lett. 1993, 173. (d) Uchida, C.; Yamagishi, T.; Ogawa, S. J . Chem. Soc., Perkin Trans. 1 1994, 589.

(7) (a) Kobayashi, Y.: Miyazaki, H.: Shiozaki, M.J . Am. Chem. Soc 1992, 114, 10065. (b) Kobayashi, Y.; Miyazaki, Shiozaki, M. Tetrahe dron Lett. 1993, 34, 1505. (c) Kobayashi, Y.; Miyazaki, H.; Shiozaki, M. J . Org. Chem. 1994, 59, 813.

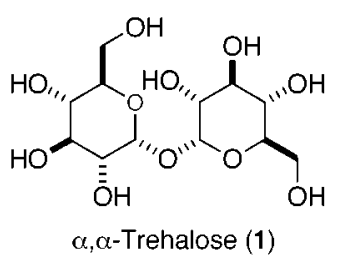<smiles>OCC1O[C@@H](N=C2N=C3[C@H](O)C(O)[C@@H](O)[C@@H]3O2)[C@H](O)[C@@H](O)[C@@H]1O</smiles><smiles>N[C@H]1[C@@H](O)C(O)[C@@H](O)C1(O)O</smiles>

Trehazolamine (3)<smiles>OCC1O[C@@H](N=C=S)C(O)[C@H](O)C1O</smiles>

Figure 1.

configuration. Trehazolin probably acts as a close mimic of the substrate $\alpha, \alpha$-trehal ose (1) or, more likely, of the postulated glycopyranosyl cation intermediate involved in the hydrolytic step of glycosides or a transition state leading to it. By systematic chemical modifications of the sugar ${ }^{10}$ and the aglycon, $, 6 \mathrm{~b}, \mathrm{~d}, 10 \mathrm{~d}, 11$ a number of structure-activity relationships have been established. All previous total syntheses of $\mathbf{2}^{6 \mathrm{~b}, \mathrm{~d}, 7 \mathrm{a}, \mathrm{c}, 9}$ followed a general retrosynthetic strategy where the molecule is assembled by linking a protected $\alpha$-D-glucosyl isothiocyanate (4) $)^{9,12}$ to free or partially protected aminocyclopentitol 3. The reported syntheses of $\mathbf{3}$ followed long sequences $(\geq 15$ steps) starting from myo-inositol, ${ }^{6}$ D-glucose, ${ }^{7}$ D-ribonolactone, ${ }^{8}$ or (R)-epichlorohydrin, ${ }^{9}$ with only modest overall yields. ${ }^{13}$ Ketyl radical cyclizations promoted by samarium diiodide are specially well-suited for this endeavor since they afford directly a functionalized cycloalkanol and proceed under mild conditions, usually in high yield and with a good level of stereocontrol. ${ }^{14}$ The use of chiral polyoxygenated precursors, conveniently prepared from carbohydrates, could allow the facile preparation in this way of enantiomerically pure complex cyclitols such as 3. ${ }^{15}$ In 1995, we reported a short and stereose-

(8) Knapp, S.; Purandare, A.; Rupitz, K.; Withers, S. G. J . Am. Chem Soc. 1994, 116, 7461.

(9) Ledford, B. E.; Carreira, E. M. J . Am. Chem. Soc. 1995, 117, $(9)$ L
11811. 
lective approach to different diastereoisomeric anal ogues of $\mathbf{3}$ following this approach. The key step was a highly efficient reductive carbocyclization of carbonyl-tethered oxime ethers prepared from readily available carbohydrate derivatives. ${ }^{16}$ We now report a new, high-yielding synthesis of $\mathbf{3}$ starting from D-gl ucose via a very efficient pinacol coupling cyclization promoted by samarium diiodide. ${ }^{17}$ This reducing agent has proven to be specially convenient at promoting intramolecular pinacol coupling reactions on polyoxygenated substrates under very mild conditions, in high yield, and with high diastereoselectivity. ${ }^{18}$

\section{Results and Discussion}

Our approach to $\mathbf{3}$ starts from hemiacetal $\mathbf{5}$ (Scheme 1), readily obtainable from D-glucose in two steps and commercially available. ${ }^{19}$ Sodium borohydride reduction

(10) (a) Uchida, C.; Kitahashi, H.; Yamagishi, T.; I waisaki, Y.; Ogawa, S. J . Chem. Soc., Perkin Trans. 1 1994, 2775. (b) Kobayashi, Y.; Shiozaki, M. J. Antibiot. 1994, 47, 243. (c) Uchida, C.; Kitahashi, H.; Watanabe, S.; Ogawa, S. J . Chem. Soc., Perkin Trans. 1 1995, 1707. (d) Uchida, C.; Yamagishi, T.; Kitahashi, H.; I waisaki, Y.; Ogawa, S Biiorg. Med. Chem. 1995, 3, 1605. (e) Kobayashi, Y.; Shiozaki, M. Ando, O. J . Org. Chem. 1995, 60, 2570. (f) Shiozaki, M.; U bukata, O.; Haruyama, H.; Yoshiike, R. Tetrahedron Lett. 1998, 39, 1925.

(11) (a) Uchida, C.; Yamagishi, T.; Ogawa, S. Chem. Lett. 1993, 971. (b) Elliot, R. P.; Hui, A.; Fairbanks, A. J .; Nash, R. J .; Winchester, B. G.; Way, G.; Smith, C.; Lamont, R. B.; Storer, R.; Fleet, G. W. J Tetrahedron Lett. 1993, 34, 7949. (c) Uchida, C.; Kitahashi, H. Yamagishi, T.; I waisaki, Y.; Ogawa, S. J . Chem. Soc., Perkin Trans. 1 1994, 2775. (d) Uchida, C.; Ogawa, S. Carbohydr. Lett. 1994, 1, 77. (e) Shiozaki, M.; Kobayashi, Y.; Arai, M.; Haruyama, H. Tetrahedron Lett. 1994, 35, 887. (f) Kobayashi, Y.; Miyazaki, H.; Shiozaki, M.; Haruyama, H. J. Antibiot. 1994, 47, 932. (g) Shiozaki, M.; Arai, M.; Kobayashi, Y.; Kasuya, A.; Miyamoto, S.; Furukawa, Y.; Takayama, T.; Haruyama, H. J . Org. Chem. 1994, 59, 4450. (h) Uchida, C.; Yamagishi, T.; Kitahashi, H.; I waisaki, Y.; Ogawa, S. Bioorg. Med. Chem. 1995, 3 1605. (i) U chida, C.; Kitahashi, H.; Watanabe, S.; Ogawa, S. J . Chem. Soc., Perkin Trans. 1 1995, 1707. (j) Uchida, C.; Ogawa, S. Bioorg. Med Chem. 1996, 4, 275. See, also: Ogawa, S. In Carbohydrate Mimics: Concepts and Methods; Chapleur, Y., Ed.; Wiley-VCH: Weinheim 1998, Chapter 5.

(12) Camarasa, M. J .; Fernández-Resa, P.; García-López, M. T.; G. delas Heras, F.; Méndez-Castrillón, P. P.; San Félix, A. Synthesis 1984, 509.

(13) After this paper was submitted for publication, a new synthesis of $\mathbf{3}$ and (+)-6-epitrehazolin appeared in the literature: Li, J .; Lang F.: Ganem, B. J. Org. Chem. 1998, 63, 3403. For a related formal synthesis of 3, see: Goering, B. K.; Li, J .; Ganem, B. Tetrahedron Lett. 1995, 36, 8905

(14) For recent reviews on applications of samarium diiodide in organic synthesis, see: (a) Molander, G. A.; Harris, G. R. Chem. Rev. 1996, 96, 307. (b) Molander, G. A. Org. React. 1994, 46. (c) Imamoto T. Lanthanides in Organic Synthesis; Academic Press: London 1994

(15) For a recent review on the use of carbohydrate templates for the preparation of carbocycles, see: Ferrier, R. J .; Middleton, S. Chem. Rev. 1993, 93, 2779.

(16) (a) Chiara, J. L.; Marco-Contelles, J .; Khiar, N.; Gallego, P. Destabel, C.; Bernabé, M. J. Org. Chem. 1995, 60, 6010. (b) MarcoContelles, J. L.; Gallego, P.; Rodríguez-Fernández, M.; Khiar, N. Destabel, C.; Bernabé, M.; Martínez-Grau, A.; Chiara, J . L. J . Org Chem. 1997, 62, 7397.

(17) A part of this work was presented at the 2nd Euroconference on Carbohydrate Mimics; Lago di Garda; 1996. See: Chiara, J. L. In Carbohydrate Mimics: Concepts and Methods; Chapleur, Y., Ed.; Wiley-VCH: 1998; chapter 7.

(18) For examples in the carbohydrate field, see: (a) Chiara, J . L.; Cabri, W.; Hanessian, S. Tetrahedron Lett. 1991, 32, 1125. (b) Uenishi, J.; Masuda, S.; Wakabayashi, S. Tetrahedron Lett. 1991, 32, 5097. (c) Chiara, J. L.; Martín-Lomas, M. Tetrahedron Lett. 1994, 35, 2969. (d) Guidot, J . P.; Le Gall, T.; Mioskowski, C. Tetrahedron Lett. 1994, 35 6671. (e) Chiara, J. L.; Valle, N. Tetrahedron: Asymmetry 1995, 6 , 1895. (f) Perrin, E.; Mallet, J .-M.; Sinä̈, P. Carbohydr. Lett. 1995, 1 215. (g) Sawada, T.: Shirai, R.; I wasaki, S. Tetrahedron Lett. 1996 37, 885. (h) Kornienko, A.; d'Alarcao, M. Tetrahedron Lett. 1997, 38 6497. (i) Carpintero, M.; Fernández-Mayoralas, A.; J aramillo, C.J . Org. Chem. 1997, 62, 1916. (j) Adinolfi, M.; Barone, G.; Iadonisi, A. Mangoni, L.; Manna, R. Tetrahedron 1997, 53, 11767. (k) J enkins, D. J .; Potter, B. V. L. J . Chem. Soc., Perkin Trans. 1 1998, 41. (I) Adinolfi, M.; Barone, G.; Iadonisi, A.; Mangoni, L. Tetrahedron Lett. 1998, 39, 2021.
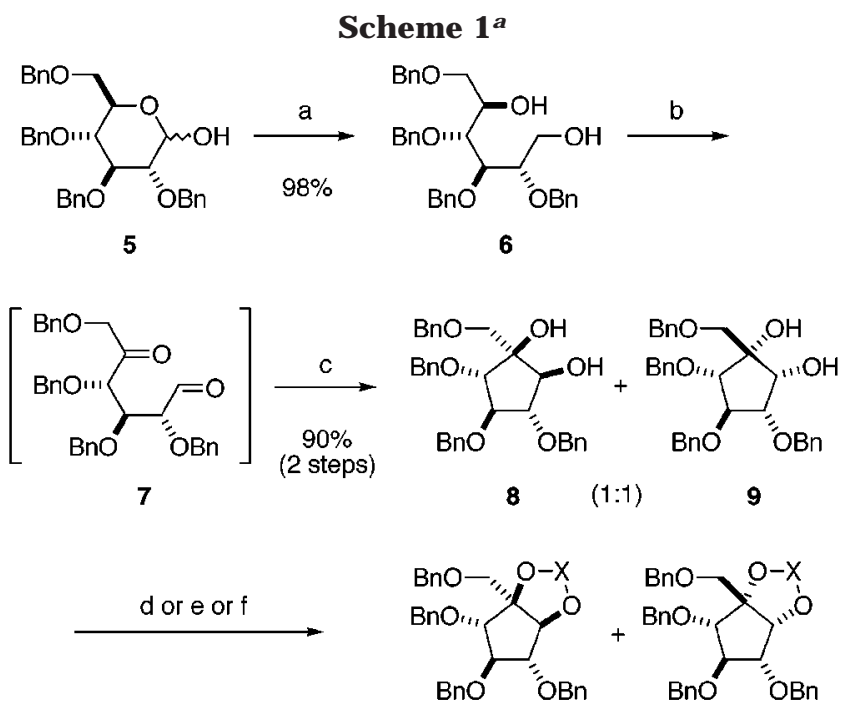

$$
\begin{array}{llll}
93 \% & \mathrm{X}=\mathrm{CMe}_{2} & \mathbf{1 0} & \mathbf{1 1} \\
91 \% & \mathrm{X}=\mathrm{SO}_{2} & \mathbf{1 2} & 13 \\
97 \% & \mathrm{X}=\mathrm{CS} & \mathbf{1 4} & 15
\end{array}
$$

a Reagents and conditions: (a) $\mathrm{NaBH}_{4}, \mathrm{EtOH} / \mathrm{CH}_{2} \mathrm{Cl}_{2}$ (1:1), rt; (b) (i) $(\mathrm{COCl})_{2}, \mathrm{DMSO}, \mathrm{THF},-65{ }^{\circ} \mathrm{C}$, (ii) $\mathrm{Et}_{3} \mathrm{~N},-65^{\circ} \mathrm{C}$ to rt; (c) $\mathrm{Sml}_{2}$, THF/t-BuOH, $-50^{\circ} \mathrm{C}$ to rt; (d) $(\mathrm{MeO})_{2} \mathrm{CMe}_{2}, \mathrm{Me}_{2} \mathrm{CO}, \mathrm{p}-\mathrm{TsOH}$ (cat.), rt; (e) (i) $\mathrm{SOCl}_{2}, \mathrm{Et}_{3} \mathrm{~N}, \mathrm{CH}_{2} \mathrm{Cl}_{2}, 0^{\circ} \mathrm{C}$, (ii) $\mathrm{RuCl}_{3}$ (cat.), $\mathrm{NalO}_{4}$, $\mathrm{MeCN} / \mathrm{CCl}_{4} / \mathrm{H}_{2} \mathrm{O}$ (1:1:1.5), rt; (f) 1,1'-thiocarbonyldiimidazole, toluene, $110^{\circ} \mathrm{C}$

afforded D-glucitol derivative $\mathbf{6}$ quantitatively. We have shown previously ${ }^{16,18 c, e}$ that, for those carbocyclizations involving an aldehyde as pinacol partner, the yield of the cyclic product can be greatly improved if the oxidation and the reductive coupling steps are performed in a one pot sequence avoiding the isolation of the intermediate dicarbonyl compound, which is usually rather unstable and prone to hydration. Thus, Swern oxidation of $\mathbf{6}$ in THF followed by dropwise addition of the crude reaction mixture of keto aldehyde 7 to a freshly prepared solution of $\mathrm{Sml}_{2}$ in $\mathrm{THF}^{20}$ containing t-BuOH at low temperature afforded a 1:1 mixture (determined by ${ }^{1} \mathrm{H}$ NMR analysis of the crude) of cyclic diols $\mathbf{8}$ and $\mathbf{9}$ in excellent yield. ${ }^{21,22}$ Although this mixture could not be separated by column chromatography, we were able to get diol $\mathbf{8}$ pure by recrystallization from EtOAc/hexane. Both cyclic products were shown to have a cis relative stereochemistry at the two new stereocenters by their ready transformation into cyclic acetals $\mathbf{1 0}$ and $\mathbf{1 1}$, cyclic sulfates $\mathbf{1 2}$ and 13, or cyclic thionocarbonates 14 and 15 (Scheme 1), which were in each case readily separable by chromatography. The cis stereoselectivity obtained in this cydization is in agreement with previous examples ${ }^{18 a-h, j-1}$

(19) Decoster, E.; Lacombe, J .-M.; Streber, J .-L.; Ferrari, B.; Pavia, A. A. J. Carbohydr. Chem. 1983, 2, 329

(20) Girard, P.; Namy, J . L.; Kagan, H. B. J . Am. Chem. Soc. 1980, $102,2693$.

(21) This key transformation has been reported very recently and independently by us ${ }^{17}$ and others (see also the preceding article in this issue: Boiron, A.; Zillig, P.; Faber, D.; Giese, B. J . Org. Chem. 1998, $63,5877) .181$ The slightly different diastereosel ectivity obtained in each case is probably a consequence of the different experimental procedures followed.

(22) Two very minor cyclopentanediols (A, 0.33\%; B, 0.53\% yield) could al so be isolated by chromatography and characterized when the reaction was performed on gram scale (see Experimental Section). Neither of these compounds formed an isopropylidene acetal, showing that they are in fact the other two possible diastereoi someric products, with trans relative stereochemistry at the new stereocenters (see Supporting Information for NOESY data). 
Scheme 2

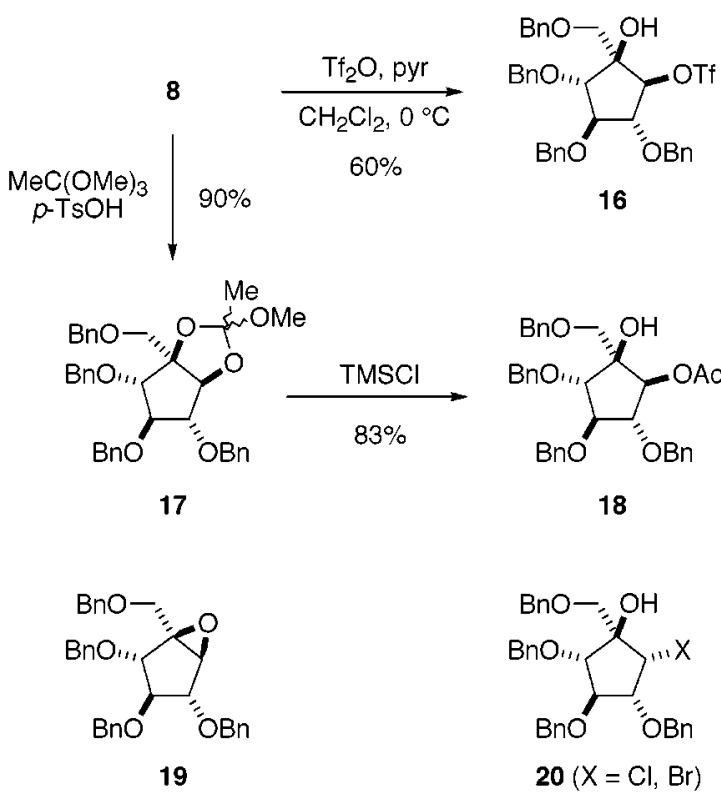

of pinacol coupling reactions promoted by samarium diiodide, and it has been attributed to the chelated nature of the transition state involved. ${ }^{18 a, 23}$ The complete stereochemistry of $\mathbf{8}$ and $\mathbf{9}$ was established by ${ }^{1} \mathrm{H}$ NMR and 2D NOESY studies (see the Supporting I nformation). Diol 8 has the correct stereochemistry of trehazolamine (3) at all except the stereocenter that should support the amino group. We expected to introduce this function via a nucleophilic displacement reaction. However, all attempts using cyclic sulfate $\mathbf{1 2}$ gave only el imination and decomposition products. The same result was obtained with monotriflate 16 (Scheme 2). ${ }^{24}$ Steric shiel ding by the flanking benzyloxy and benzyloxymethyl groups probably impedes the attack of the nucleophile in the $\mathrm{S}_{\mathrm{N}} 2$ trajectory. To circumvent these difficulties, we decided to use a reductive amination strategy. However, the different conditions tried to selectively oxidize the secondary al cohol ${ }^{25}$ produced either keto aldehyde 7 (isolated as its cyclic monohydrated hemiacetal) or elimination and decomposition products. Since in other reported approaches ${ }^{7,11 b, e-g}$ to trehazolamine and analogues the amino group was introduced uneventfully via azide opening of an epoxide, we tried to transform diol 8 into the corresponding epoxide $\mathbf{1 9}$ of the same sterochemistry (Scheme 2). However, attempts to convert $\mathbf{8}$ directly into halohydrin 20 using $\mathrm{Me}_{2} \mathrm{C}(\mathrm{OAc}) \mathrm{COX}(\mathrm{X}=\mathrm{Cl} \text { or } \mathrm{Br})^{26}$ gave monoacetate $\mathbf{1 8}$ and decomposition products. A similar result was obtained when Sharpless' procedure ${ }^{27}$ was tried. Thus, treatment of cyclic ortho ester 17 (1:1 mixture of diastereoisomers) with $\mathrm{TMSCl}$ or $\mathrm{AcCl}$ produced again 18 instead of the expected chlorohydrin $\mathbf{2 0}$ $(\mathrm{X}=\mathrm{Cl})$.

In all these failed routes to trehazolamine, one-half of the pinacol coupling product (the "wrong" diastereoisomer

(23) Molander, G. A.; Kenny, C. J . Am. Chem. Soc. 1989, 111, 8236 (24) We used different conditions: $\mathrm{NaN}_{3}$ or $\mathrm{LiN}_{3}$ in DMF at room temperature to $125{ }^{\circ} \mathrm{C}, \mathrm{n}-\mathrm{Bu}_{4} \mathrm{NN}_{3}$ in $\mathrm{DMF}$ or toluene at room temperature to $125^{\circ} \mathrm{C}$.

(25) PCC produced an elimination product, Swern gave decomposition, Dess-Martin periodinane produced keto aldehyde $\mathbf{8}$, and $n-B_{2}$ $\mathrm{SnO} / \mathrm{Br}_{2}$ afforded only starting material

(26) (a) Greenberg, S.; M offatt, J . G. J . Am. Chem. Soc. 1973, 95, 4016. (b) Robins, M.J .; Hansske, F.; Low, N. H.; Park, J . I. Tetrahedron Lett. 1984, 25, 367.

(27) Kolb, H. C.; Sharpless, K. B. Tetrahedron 1992, 48, 10515.
Scheme 3

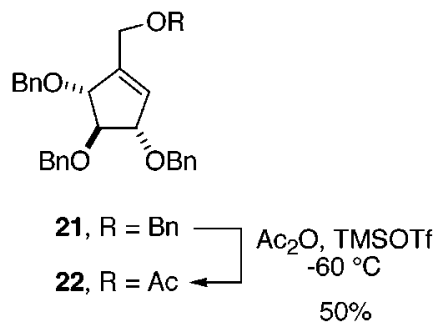

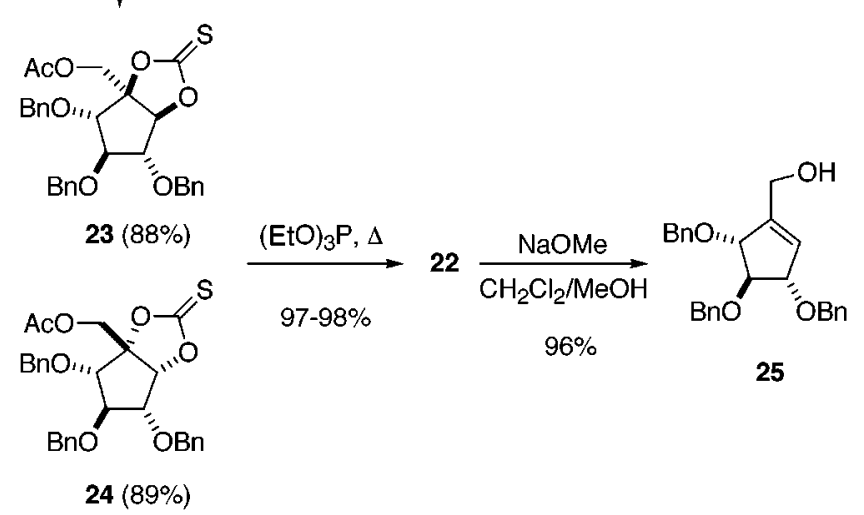

9) was being discarded. A route where both diastereoisomeric diols, 8 and $\mathbf{9}$, could be carried through to $\mathbf{3}$ was evidently highly desirable. With this objective, the mixture of cyclic thionocarbonates 14 and $\mathbf{1 5}$ was converted into the common elimination product $\mathbf{2 1}$ in very good yield by heating with triethyl phosphite ${ }^{28}$ (Scheme 3). At this point we were prepared to install the requisite 1,2-amino alcohol functionality in a stepwise manner through stereoselective epoxidation of the double bond followed by regiosel ective epoxide opening with a nitrogen nucleophile. However, epoxidation of $\mathbf{2 1}$ with m-CPBA furnished an inseparable mixture of epoxides (ratio 1.6: 1, determined by ${ }^{1} \mathrm{H}$ NMR analysis of the crude). ${ }^{29}$ To overwhel $m$ the modest diastereofacial preference exhibited by $\mathbf{2 1}$, a reagent-control strategy, Sharpless epoxidation, ${ }^{30}$ was in order. But prior to oxidation, a selective deprotection of the primary hydroxyl group of $\mathbf{2 1}$ was needed. This could be achieved via an acetolysismethanolysis sequence. Treatment of $\mathbf{2 1}$ with TMSOTf in $\mathrm{Ac}_{2} \mathrm{O}^{31}$ at low temperature afforded monoacetate $\mathbf{2 2}$ in modest yield due to its instability under the reaction conditions. Other conditions tried did not improve this result. ${ }^{32}$ However, the yield of monoacetate was doubled when the acetolysis was performed on the cyclic thionocarbonates $\mathbf{1 4}$ and $\mathbf{1 5}$ (Scheme 3). The monoacetates $\mathbf{2 3}$ and $\mathbf{2 4}$ obtained in this way were heated with triethyl phosphite, ${ }^{28}$ giving $\mathbf{2 2}$ in excellent yield. Methanolysis of $\mathbf{2 2}$ under basic conditions afforded the allylic alcohol 25. Sharpless epoxidation of $\mathbf{2 5}$ with diisopropyl Ltartrate, titanium tetraisopropoxide, and tert-butyl hydroperoxide yielded the desired epoxide $\mathbf{2 6}$ in very high yield (Scheme 4). ${ }^{29,33}$ Using diisopropyl D-tartrate furnished the other epoxide $\mathbf{2 8}$ as a single diastereoisomer. ${ }^{29}$

(28) Corey, E. J .; Winter, R. A. E. J . Am. Chem. Soc. 1963, 85, 2677

(29) A similar result was obtained by Shiozaki et al. ${ }^{7 c}$ for the epoxidation of a closely related cyclopentene derivative

(30) Katsuki, T.; Sharpless, K. B. J . Am. Chem. Soc. 1980, 102, 5974. For a recent review, see: J ohnson, R. A.; Sharpless, K. B. In Catalytic Asymmetric Synthesis; Ojima, I., Ed.; VCH Publishers: New York 1993; pp 103-158

(31) (a) Angibeaud, P.; Utille, J .-P. J . Chem. Soc., Perkin Trans. 1 1990, 1490. (b) Angibeaud, P.; Utille, J.-P. Synthesis 1991, 737.

(32) Ynag, G.; Ding, X.; Kong, F. Tetrahedron Lett. 1997, 38, 6725. 


\section{Scheme 4}

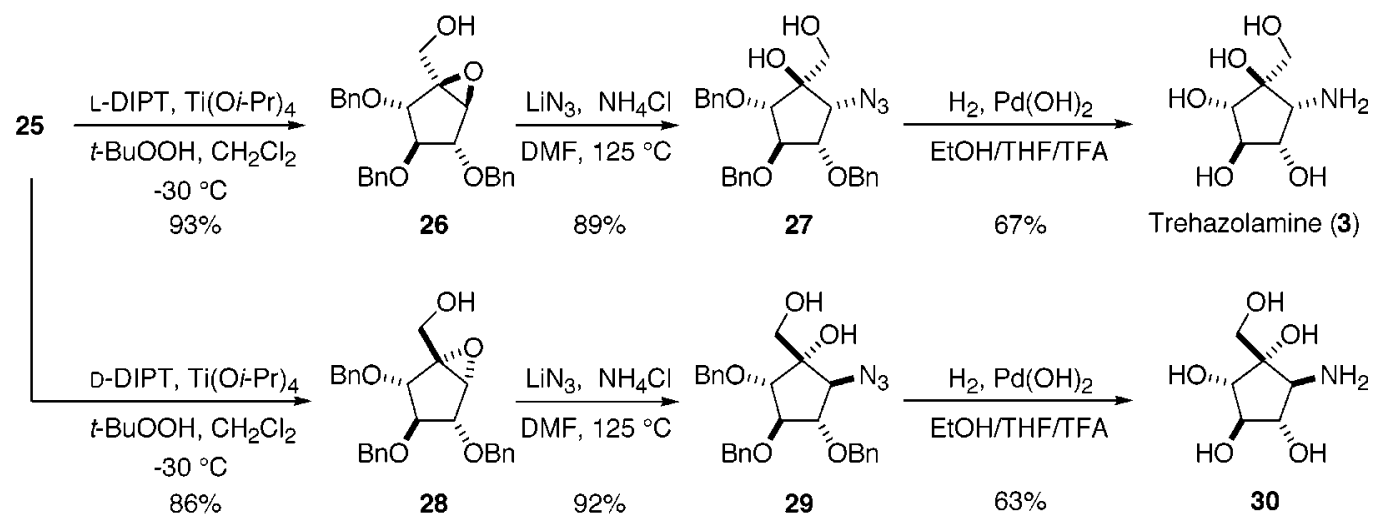

Scheme 5

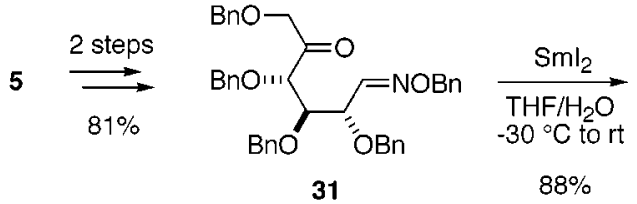<smiles>NC1[C@H](OCc2ccccc2)[C@H](OCc2ccccc2)[C@@H](OCc2ccccc2)[C@H]1OCc1ccccc1</smiles>

These stereochemical results are in agreement with Sharpless' empirical rule. ${ }^{30}$ Opening of $\mathbf{2 6}$ with $\mathrm{LiN}_{3} /$ $\mathrm{NH}_{4} \mathrm{Cl}^{34}$ in DMF yiel ded azi de $\mathbf{2 7}$ regioselectively and in high yield. Hydrogenolysis of $\mathbf{2 7}$ gave finally trehazolamine (3), whose physical and spectroscopic data were identical to those described for natural ${ }^{5 b}$ and synthetic ${ }^{6 a, 7 c}$ 3. An analogous sequence produced trehazolamine diastereoisomer $\mathbf{3 0}$ from epoxide $\mathbf{2 8}$. The described approach produces trehazolamine (3) in nine steps in an exceedingly good $39 \%$ overall yield from readily available D-glucose derivative 5 . The preparation of trehazolin (1) from aminocyclitol $\mathbf{3}$ has been already described in the literature. ${ }^{6 c, d, 9}$

A shorter, more direct route to $\mathbf{3 0}$ was also developed from D-glucose (Scheme 5). Reductive carbocyclization of readily available ${ }^{15}$ keto oxime ether $\mathbf{3 1}$ using an excess of samarium diiodide, under conditions previously de scribed by us, ${ }^{16}$ took place with subsequent $\mathrm{N}-\mathrm{O}$ reductive cleavage, affording directly the aminocyclopentitol 32 in an excellent overall yield. Hydrogenolysis of $\mathbf{3 2}$ afforded finally 30 . This route produced the unnatural trehazol amine anal ogue $\mathbf{3 0}$ in only four steps from $\mathbf{5}$ (six steps from D-glucose) and 57\% overall yield.

\section{Conclusion}

The described synthesis of $\mathbf{3}$ and $\mathbf{3 0}$ demonstrate the general effectiveness of ketyl radical cyclizations promoted by samarium diiodide for the efficient preparation of densely functionalized cyclitols under very mild conditions and using readily available carbohydrate derivatives as starting materials. The one-pot sequence of

(33) Traces ( $\leq 1 \%$ ) of the other epoxide could be observed in the ${ }^{1} \mathrm{H}$ NMR of the crude reaction mixture.

(34) VanderWerf, C. A.; Heisler, R. Y.; McE wen, W. E.J . Am. Chem Soc. 1954, 76, 1231.
Swern oxidation and reductive carbocyclization has proved to be very advantageous when the coupling involves an aldehyde, giving higher overall yields than the alternative two-step process.

\section{Experimental Section}

General. NMR sepctra were recorded at 200, 300, or 400 $\mathrm{MHz}\left({ }^{1} \mathrm{H}\right.$ frequency) and at $30^{\circ} \mathrm{C}$. Tetrahydrofuran (THF) was distilled under argon from sodium-benzophenone, and $\mathrm{CH}_{2-}$ $\mathrm{Cl}_{2}$ was distilled from $\mathrm{CaH}_{2}$. All reactions were performed under argon with anhydrous freshly distilled solvents. Samarium diiodide was prepared immediately before use by adding $\mathrm{ICH}_{2} \mathrm{CH}_{2} \mathrm{I}$ in one portion to a suspension of samarium metal powder (1.2 equiv) in THF (10 mL/mmol of $\left.\mathrm{ICH}_{2} \mathrm{CH}_{2} \mathrm{I}\right)$ under argon and stirring vigorously the resultant suspension for $1-2$ h. ${ }^{20}$ The reductive carbocyclizations were performed in the presence of the slight excess of samarium metal used in the preparation of the reagent.

2,3,4,6-Tetra-O-benzyl-D-glucitol (6). To a solution of 2,3,4,6-tetra-O-benzyl-D-glucopiranose ${ }^{19}(5.84 \mathrm{~g}, 10.84 \mathrm{mmol})$ in $\mathrm{EtOH} / \mathrm{CH}_{2} \mathrm{Cl}_{2}$ 1:1 (59 mL) at room temperature was added $\mathrm{NaBH}_{4}(1.64 \mathrm{~g}, 43.21 \mathrm{mmol})$. After completion of the reaction, $2 \mathrm{M} \mathrm{HCl}(30 \mathrm{~mL}$ ) was slowly added, the phases were separated, and the aqueous phase was extracted with $\mathrm{CH}_{2} \mathrm{Cl}_{2}(2 \times 40 \mathrm{~mL})$. The combined organic extracts were dried $\left(\mathrm{Na}_{2} \mathrm{SO}_{4}\right)$ and the solvent was evaporated at reduced pressure. The residue was purified by flash chromatography (EtOAc/hexane 1:3), affording $6\left(5.74 \mathrm{~g}, 98 \%\right.$ ) as a col orless oil. $R_{f}=0.37$ (EtOAc/hexane 1:2); $[\alpha]^{22} \mathrm{D}+9.9\left(\mathrm{c} 1.5, \mathrm{CHCl}_{3}\right) ;{ }^{1} \mathrm{H} \mathrm{NMR}\left(\mathrm{CDCl}_{3}\right) \delta 7.41-7.27$ $(\mathrm{m}, 2 \mathrm{H}), 4.79(\mathrm{~d}, 1 \mathrm{H}, \mathrm{J}=11.3 \mathrm{~Hz}), 4.79(\mathrm{~d}, 1 \mathrm{H}, \mathrm{J}=11.6 \mathrm{~Hz})$, $4.71(\mathrm{~d}, 1 \mathrm{H}, \mathrm{J}=11.3 \mathrm{~Hz}), 4.68(\mathrm{~d}, 1 \mathrm{H}, \mathrm{J}=11.6 \mathrm{~Hz}), 4.67(\mathrm{~d}$, $1 \mathrm{H}, \mathrm{J}=11.3 \mathrm{~Hz}), 4.62(\mathrm{~d}, 1 \mathrm{H}, \mathrm{J}=11.9 \mathrm{~Hz}), 4.60(\mathrm{~d}, 1 \mathrm{H}, \mathrm{J}=$ $11.3 \mathrm{~Hz}), 4.55(\mathrm{~d}, 1 \mathrm{H}, \mathrm{J}=11.9 \mathrm{~Hz}), 4.13-4.06(\mathrm{~m}, 1 \mathrm{H}), 3.96$ $(\mathrm{dd}, 1 \mathrm{H}, \mathrm{J}=6.2,3.6 \mathrm{~Hz}), 3.91-3.75(\mathrm{~m}, 3 \mathrm{H}), 3.71-3.61(\mathrm{~m}$, $3 \mathrm{H}), 3.04(\mathrm{~d}, 1 \mathrm{H}, \mathrm{J}=5.2 \mathrm{~Hz}), 2.25(\mathrm{t}, 1 \mathrm{H}, \mathrm{J}=6.3 \mathrm{~Hz}) ;{ }^{13} \mathrm{C}$ NMR $\left(\mathrm{CDCl}_{3}\right) \delta 142.2,142.0,141.8,141.6,132.4-131.5(20 \mathrm{C})$, 83.3, 82.9, 81.4, 81.2, 80.8, 80.2, 78.2, 74.9, 74.5, 65.6.

Cyclization of Compound 6 through a One-Pot Swern Oxidation-Sml 2 Reductive Coupling Process. Synthesis of [1S-(1 $\alpha, 2 \alpha, 3 \beta, 4 \alpha, 5 \beta)]-3,4,5-\operatorname{tris}$ (benzyloxy)1-(benzyloxymethyl)-1,2-cyclopentanediol (8) and [1R$(1 \alpha, 2 \alpha, 3 \alpha, 4 \beta, 5 \alpha)]-3,4,5-t r i s($ benzyloxy)-1-(benzyloxymethyl)1,2-cyclopentanediol (9). To a solution of $(\mathrm{COCl})_{2}(1.9 \mathrm{~mL}$, $21.84 \mathrm{mmol})$ in THF $(39 \mathrm{~mL})$ at $-65^{\circ} \mathrm{C}$ was added dropwise a solution of DMSO $(3.4 \mathrm{~mL}, 43.67 \mathrm{mmol})$ in THF $(39 \mathrm{~mL})$. After stirring for $15 \mathrm{~min}$ at $-65^{\circ} \mathrm{C}$, a solution of $\mathbf{6}(3.95 \mathrm{~g}, 7.28 \mathrm{mmol})$ in THF (15 mL $+6 \mathrm{~mL}$ rinse) was added dropwise. After stirring at $-65{ }^{\circ} \mathrm{C}$ for $45 \mathrm{~min}, \mathrm{Et}_{3} \mathrm{~N}(10.2 \mathrm{~mL}, 72.79 \mathrm{mmol})$ was added dropwise and the reaction was stirred from -65 ${ }^{\circ} \mathrm{C}$ to room temperature for $1 \mathrm{~h}$. The reaction mixture was diluted with THF $(47 \mathrm{~mL})$ and added dropwise to a freshly prepared $0.1 \mathrm{M}$ solution of $\mathrm{Sml}{ }_{2}$ in THF $(218 \mathrm{~mL}, 21.84 \mathrm{mmol})$ and t-BuOH $(1.66 \mathrm{~mL}, 18.20 \mathrm{mmol})$ at $-50^{\circ} \mathrm{C}$. After stirring at $-50{ }^{\circ} \mathrm{C}$ for $3 \mathrm{~h}$, the reaction was allowed to slowly attain room temperature overnight. Aqueous saturated $\mathrm{NaHCO}_{3}$ 
$(200 \mathrm{~mL}$ ) was added to the reaction mixtureand, after stirring for $30 \mathrm{~min}$, the aqueous phase was extracted with EtOAc $(4 \times$ $150 \mathrm{~mL}$ ). The combined organic extracts were washed with $10 \%$ aqueous $\mathrm{Na}_{2} \mathrm{~S}_{2} \mathrm{O}_{3}$ and dried over $\mathrm{Na}_{2} \mathrm{SO}_{4}$. The mixture was filtered and solvent was removed at reduced pressure. The crude was purified by flash chromatography (EtOAc/hexane 1:5), affording an inseparable 1:1 mixture of cis diols 8 and $\mathbf{9}$ (3.54 g, 90\%), and the trans diols A (13 mg, 0.33\%) and B (21 $\mathrm{mg}, 0.53 \%$ ). A pure sample of $\mathbf{8}$ was obtained by fractional crystallization from EtOAc/hexane. 8: white solid. $R_{f}=0.18$ (EtOAc/hexane 1:3); $\mathrm{mp} 101-103{ }^{\circ} \mathrm{C} ;[\alpha]^{22} \mathrm{D}+1.85$ (c 1.3, $\left.\mathrm{CHCl}_{3}\right) ;{ }^{1} \mathrm{H} \mathrm{NMR}\left(\mathrm{CDCl}_{3}\right) \delta 7.37-7.24(\mathrm{~m}, 2 \mathrm{H}), 4.77(\mathrm{~d}, 1 \mathrm{H}, \mathrm{J}$ $=11.8 \mathrm{~Hz}), 4.63(\mathrm{~d}, 1 \mathrm{H}, 11.8 \mathrm{~Hz}), 4.58-4.56(\mathrm{~m}, 6 \mathrm{H}), 4.02(\mathrm{t}$, $1 \mathrm{H}, \mathrm{J}=5.3 \mathrm{~Hz}), 3.97(\mathrm{td}, 1 \mathrm{H}, \mathrm{J}=5.8,0.8 \mathrm{~Hz}), 3.88(\mathrm{~d}, 1 \mathrm{H}, \mathrm{J}$ $=4.5 \mathrm{~Hz}), 3.83(\mathrm{td}, 1 \mathrm{H}, \mathrm{J}=4.8,0.7 \mathrm{~Hz}), 3.81(\mathrm{~d}, 1 \mathrm{H}, \mathrm{J}=9.6$ $\mathrm{Hz}), 3.66(\mathrm{~d}, 1 \mathrm{H}, \mathrm{J}=9.6 \mathrm{~Hz}), 3.20(\mathrm{~s}, 1 \mathrm{H}), 2.70(\mathrm{~d}, 1 \mathrm{H}, \mathrm{J}=4.9$ $\mathrm{Hz}) ;{ }^{13} \mathrm{C} \mathrm{NMR}\left(\mathrm{CDCl}_{3}\right) \delta 138.3,138.1,137.9,137.5,128.4-$ 127.5 (20 C), 87.0, 85.8, 85.3, 78.5, 77.1, 73.8, 72.4, 72.0, 71.8, 71.7. Anal. Calcd for $\mathrm{C}_{34} \mathrm{H}_{36} \mathrm{O}_{6}$ : C, 75.53; $\mathrm{H}, 6.71$. Found: C, 75.81; $\mathrm{H}, 6.80 .9$ (as a mixture with 8): $\mathrm{R}_{\mathrm{f}}=0.18$ (EtOACl hexane 1:3); ${ }^{1} \mathrm{H} \mathrm{NMR}\left(\mathrm{CDCl}_{3}\right) \delta 7.39-7.24(\mathrm{~m}, 2 \mathrm{OH}), 4.73-$ $4.47(\mathrm{~m}, 8 \mathrm{H}), 4.14(\mathrm{dd}, 1 \mathrm{H}, \mathrm{J}=5.7,4.8 \mathrm{~Hz}), 4.09(\mathrm{t}, 1 \mathrm{H}, \mathrm{J}=$ $6.4 \mathrm{~Hz}), 3.90(\mathrm{~d}, 1 \mathrm{H}, \mathrm{J}=6.0 \mathrm{~Hz}), 3.86(\mathrm{dd}, 1 \mathrm{H}, \mathrm{J}=6.0,4.6$ $\mathrm{Hz}), 3.47(\mathrm{~d}, 1 \mathrm{H}, \mathrm{J}=9.4 \mathrm{~Hz}), 3.41(\mathrm{~d}, 1 \mathrm{H}, \mathrm{J}=9.5 \mathrm{~Hz}), 3.11(\mathrm{~s}$, $1 \mathrm{H}), 2.94(\mathrm{~d}, 1 \mathrm{H}, \mathrm{J}=7.4 \mathrm{~Hz}) ;{ }^{13} \mathrm{C} \mathrm{NMR}\left(\mathrm{CDCl}_{3}\right) \delta 138.2,138.0$, $137.9,137.7,128.5-126.9$ (20C), 87.6, 81.6, 81.2, 77.3, 73.5, 73.1, 72.7, 72.2, 71.4, 70.5. A: $R_{f}=0.28$ (EtOAc/hexane 1:3); ${ }^{1} \mathrm{H} \mathrm{NMR}\left(\mathrm{CDCl}_{3}\right) \delta 7.37-7.23(\mathrm{~m}, 2 \mathrm{OH}), 4.67(\mathrm{~d}, 1 \mathrm{H}, \mathrm{J}=11.6$ $\mathrm{Hz}), 4.62-4.54(\mathrm{~m}, 6 \mathrm{H}), 4.53(\mathrm{~d}, 1 \mathrm{H}, \mathrm{J}=11.8 \mathrm{~Hz}), 4.15(\mathrm{t}, 1 \mathrm{H}$, \rfloor$=4.9 \mathrm{~Hz}), 4.07(\mathrm{dd}, 1 \mathrm{H}, \mathrm{J}=5.2,4.1 \mathrm{~Hz}), 4.01(\mathrm{td}, 1 \mathrm{H}, \mathrm{J}=$ 5.1, $1.1 \mathrm{~Hz}), 3.95(\mathrm{~d}, 1 \mathrm{H}, \mathrm{J}=9.6 \mathrm{~Hz}), 3.81(\mathrm{dd}, 1 \mathrm{H}, \mathrm{J}=4.1$, $1.1 \mathrm{~Hz}), 3.80(\mathrm{~d}, 1 \mathrm{H}, \mathrm{J}=9.6 \mathrm{~Hz}), 2.95(\mathrm{~s}, 1 \mathrm{H}), 2.80(\mathrm{~d}, 1 \mathrm{H}, \mathrm{J}$ $=5.1 \mathrm{~Hz}) ;{ }^{13} \mathrm{C} \mathrm{NMR}\left(\mathrm{CDCl}_{3}\right) \delta 138.1,138.0,137.81,137.76$, 128.5-127.7 (20 C), 88.0, 87.6, 83.2, 80.4, 75.9, 73.8, 72.6, 72.3, 71.9, 70.4. B: $\mathrm{R}_{\mathrm{f}}=0.17$ (EtOAc/hexane 1:3); ${ }^{1 \mathrm{H} ~ N M R}\left(\mathrm{CDCl}_{3}\right)$ o $7.40-7.24(\mathrm{~m}, 2 \mathrm{H}), 4.81-4.43(\mathrm{~m}, 8 \mathrm{H}), 4.10-4.05(\mathrm{~m}, 2 \mathrm{H})$, $3.91(\mathrm{~d}, 1 \mathrm{H}, \mathrm{J}=7.1 \mathrm{~Hz}), 3.75(\mathrm{t}, 1 \mathrm{H}, \mathrm{J}=6.6 \mathrm{~Hz}), 3.57(\mathrm{~d}, 1 \mathrm{H}$, $\mathrm{J}=9.8 \mathrm{~Hz}), 3.49(\mathrm{~d}, 1 \mathrm{H}, \mathrm{J}=9.8 \mathrm{~Hz}), 3.04(\mathrm{~d}, 1 \mathrm{H}, \mathrm{J}=5.6 \mathrm{~Hz})$, $2.99(\mathrm{~s}, 1 \mathrm{H})$.

Synthesis of Acetals $\mathbf{1 0}$ and 11. To a solution of $\mathbf{8}$ and $\mathbf{9}$ (10 $\mathrm{mg}, 0.018 \mathrm{mmol}$ ) in acetone $(0.5 \mathrm{~mL})$ and 2,2-dimethoxypropane $(0.5 \mathrm{~mL})$ was added a catalytic amount of PPTS. The mixture was stirred at room temperature for $3 \mathrm{~h}$. After adding $\mathrm{Et}_{3} \mathrm{~N}(250 \mu \mathrm{L})$, the solvent was removed at reduced pressure and the residue was purified by flash chromatography (EtOAC hexane 1:8) to afford 10 (4.5 mg, 43\%) and $\mathbf{1 1}(5.2 \mathrm{mg}, 50 \%)$. 10: $\mathrm{R}_{\mathrm{f}}=0.53$ (EtOAc/hexane 1:2); ${ }^{1} \mathrm{H} \mathrm{NMR}\left(\mathrm{CDCl}_{3}\right) \delta 7.37-$ $7.25(\mathrm{~m}, 2 \mathrm{H}), 4.81-4.52(\mathrm{~m}, 9 \mathrm{H}), 4.11(\mathrm{dd}, 1 \mathrm{H}, \mathrm{J}=9.7,6.6$ $\mathrm{Hz}$ ), 4.02 (dd, $1 \mathrm{H}, \mathrm{J}=9.4,0.8 \mathrm{~Hz}$ ), 3.94 (ddd, $1 \mathrm{H}, \mathrm{J}=6.6,2.5$, $0.8 \mathrm{~Hz}), 3.73(\mathrm{~s}, 2 \mathrm{H}), 1.48(\mathrm{~s}, 3 \mathrm{H}), 1.40(\mathrm{~s}, 3 \mathrm{H}) ;{ }^{13} \mathrm{C} \mathrm{NMR}\left(\mathrm{CDCl}_{3}\right)$ $\delta 138.6,138.2,138.1,138.0,128.3-127.1$ (20 C), 113.1, 88.2, 87.5, 86.6, 85.1, 83.5, 73.7, 72.9, 72.7, 71.7, 69.7, 28.4, 26.8. 11: $\mathrm{R}_{\mathrm{f}}=0.45$ (EtOAc/hexane 1:2); ${ }^{1} \mathrm{H} \mathrm{NMR}\left(\mathrm{CDCl}_{3}\right) \delta 7.37-$ $7.17(\mathrm{~m}, 20 \mathrm{H}), 4.84-4.41(\mathrm{~m}, 8 \mathrm{H}), 4.36(\mathrm{dd}, 1 \mathrm{H}, \mathrm{J}=4.2 \mathrm{~Hz})$, $4.30(\mathrm{dd}, 1 \mathrm{H}, \mathrm{J}=9.0,7.8 \mathrm{~Hz}), 3.69(\mathrm{~d}, 1 \mathrm{H}, \mathrm{J}=7.8 \mathrm{~Hz}), 3.66$ (dd, $1 \mathrm{H}, \mathrm{J}=9.0,4.2 \mathrm{~Hz}), 3.47(\mathrm{~d}, 1 \mathrm{H}$, J $=9.4 \mathrm{~Hz}), 3.42(\mathrm{~d}, 1 \mathrm{H}$, $\mathrm{J}=9.4 \mathrm{~Hz}), 1.38(\mathrm{~s}, 3 \mathrm{H}), 1.26(\mathrm{~s}, 3 \mathrm{H}) ;{ }^{13} \mathrm{C} \mathrm{NMR}\left(\mathrm{CDCl}_{3}\right) \delta 138.7$ 138.6, 138.2, 137.7, 128.4-127.4 (20 C), 112.2, 86.4, 84.3, 80.2, 79.7, 78.8, 73.6, 73.1, 72.8, 72.3, 72.0, 26.8, 26.7.

Synthesis of Cyclic Sulfates $\mathbf{1 2}$ and 13. To a solution of $8(33 \mathrm{mg}, 0.06 \mathrm{mmol})$ in $\mathrm{CH}_{2} \mathrm{Cl}_{2}(0.5 \mathrm{~mL})$ at $0{ }^{\circ} \mathrm{C}$ were added $\mathrm{Et}_{3} \mathrm{~N}(34 \mu \mathrm{L}, 0.24 \mathrm{mmol})$ and $\mathrm{SOCl}_{2}(7 \mu \mathrm{L}, 0.09 \mathrm{mmol})$ at $0{ }^{\circ} \mathrm{C}$. After stirring at $0{ }^{\circ} \mathrm{C}$ for $20 \mathrm{~min}$, the reaction was diluted with $\mathrm{Et}_{2} \mathrm{O}$ and extracted twice with water. The combined organic phases were dried over $\mathrm{MgSO}_{4}$ and filtered, and the solvent was removed at reduced pressure. The residue was dissolved in $\mathrm{CCl}_{4} / \mathrm{CH}_{3} \mathrm{CN} / \mathrm{H}_{2} \mathrm{O}$ 1:1:1.5 $(0.7 \mathrm{~mL})$ and cooled to $0{ }^{\circ} \mathrm{C}$. Nal $\mathrm{N}_{4}$ (26 mg, $0.12 \mathrm{mmol}$ ) and a catalytic amount of $\mathrm{RuCl}_{3} \cdot \mathrm{H}_{2} \mathrm{O}$ were added, and the solution was stirred vigorously for $30 \mathrm{~min}$ at 0 ${ }^{\circ} \mathrm{C}$. The reaction was diluted with $\mathrm{Et}_{2} \mathrm{O}$, and the organic layer was washed with brine, concentrated, and filtered through silica. The solvent was removed at reduced pressure to afford 12 (33 mg, 91\%). Following the same procedure for the mixture of diols $\mathbf{8}$ and $\mathbf{9}$, both sulfates 12 and $\mathbf{1 3}$ were obtained in similar yields and could be easily separated by flash chromatography (EtOAc/hexane 1:10). 12: colorless oil; $\mathrm{R}_{\mathrm{f}}=$ 0.46 (EtOAc/hexane 1:3); ${ }^{1} \mathrm{H}$ NMR $\left(\mathrm{CDCl}_{3}\right) \delta 7.38-7.25(\mathrm{~m}$ $20 \mathrm{H}), 5.09(\mathrm{~d}, 1 \mathrm{H}, \mathrm{J}=4.7 \mathrm{~Hz}), 4.75-4.56(\mathrm{~m}, 8 \mathrm{H}), 4.37(\mathrm{~d}$ $1 \mathrm{H}, \mathrm{J}=9.4 \mathrm{~Hz}$ ), $4.23(\mathrm{dd}, 1 \mathrm{H}, \mathrm{J}=8.2,4.7 \mathrm{~Hz}), 3.97(\mathrm{dd}, 1 \mathrm{H}$, $\mathrm{J}=9.4,8.2 \mathrm{~Hz}), 3.81(\mathrm{~s}, 2 \mathrm{H}) ;{ }^{13} \mathrm{C} \mathrm{NMR}\left(\mathrm{CDCl}_{3}\right) \delta 137.7,136.9$, 136.8, 136.7, 128.5-127.6 (20 C), 91.4, 85.9, 84.7, 82.6, 82.0, 73.9, 73.8, 73.2, 72.5, 67.6; 13: colorless oil; $\mathrm{R}_{\mathrm{f}}=0.35$ (EtOAd hexane 1:3); ${ }^{1} \mathrm{H}$ NMR $\left(\mathrm{CDCl}_{3}\right) \delta 7.40-7.29(\mathrm{~m}, 18 \mathrm{H}), 7.20-$ $7.16(\mathrm{~m}, 2 \mathrm{H}), 4.89(\mathrm{~d}, 1 \mathrm{H}, \mathrm{J}=4.8 \mathrm{~Hz}), 4.85(\mathrm{~d}, 1 \mathrm{H}, \mathrm{J}=11.5$ $\mathrm{Hz}), 4.75(\mathrm{~d}, 1 \mathrm{H}, \mathrm{J}=11.5 \mathrm{~Hz}), 4.73-4.55(\mathrm{~m}, 4 \mathrm{H}), 4.42(\mathrm{t}, 1 \mathrm{H}$, $\mathrm{J}=9.0 \mathrm{~Hz}), 4.42(\mathrm{~d}, 1 \mathrm{H}, \mathrm{J}=11.7 \mathrm{~Hz}), 4.33(\mathrm{~d}, 1 \mathrm{H}, \mathrm{J}=11.7$ $\mathrm{Hz}), 3.94(\mathrm{~d}, 1 \mathrm{H}, \mathrm{J}=8.8 \mathrm{~Hz}), 3.79(\mathrm{dd}, 1 \mathrm{H}, \mathrm{J}=9.3,4.8 \mathrm{~Hz})$, $3.67(\mathrm{~d}, 1 \mathrm{H}, \mathrm{J}=9.4 \mathrm{~Hz}), 3.49(\mathrm{~d}, 1 \mathrm{H}, \mathrm{J}=9.4 \mathrm{~Hz}) ;{ }^{13} \mathrm{C} \mathrm{NMR}$ $\left(\mathrm{CDCl}_{3}\right) \delta 138.0,137.4,136.9,136.5,128.6-127.8$ (20 C), 88.0, $84.4,81.2,78.0,77.9,73.9(2 \mathrm{C}), 73.5,72.6,68.8$.

Synthesis of Cyclic Thionocarbonates 14 and 15. A solution of the 1:1 mixture of 8 and $\mathbf{9}(612 \mathrm{mg}, 1.13 \mathrm{mmol})$ and 1,1'-thiocarbonyldiimidazole (303 $\mathrm{mg}, 1.70 \mathrm{mmol}$ ) in toluene $(7.2 \mathrm{~mL})$ was heated at reflux for $4 \mathrm{~h}$. After removal of the solvent at reduced pressure, the crude product was purified by flash col umn chromatography (EtOAc/hexane 1:6), to afford $\mathbf{1 4}(296 \mathrm{mg}, 45 \%)$ and $\mathbf{1 5}(342 \mathrm{mg}, 52 \%)$. 14: colorless oil. $R_{f}=0.45$ (EtOAc/hexane 1:4); $[\alpha]^{22}{ }_{\mathrm{D}}-3.1$ (c 1.0, $\mathrm{CHCl}_{3}$ ); IR (film) 2880, 1455, 1320, 1100, $700 \mathrm{~cm}^{-1}$; ${ }^{1} \mathrm{H}$ NMR $\left(\mathrm{CDCl}_{3}\right)$ $\delta$ 7.39-7.27 (m, 20H), $5.08(\mathrm{~d}, 1 \mathrm{H}, \mathrm{J}=4.5 \mathrm{~Hz}), 4.78-4.56(\mathrm{~m}$, $8 \mathrm{H}), 4.20(\mathrm{~d}, 1 \mathrm{H}, \mathrm{J}=8.4 \mathrm{~Hz}), 4.09(\mathrm{dd}, 1 \mathrm{H}, \mathrm{J}=7.6,4.5 \mathrm{~Hz})$, $3.95(\mathrm{t}, 1 \mathrm{H}, \mathrm{J}=8.4 \mathrm{~Hz}), 3.86(\mathrm{~d}, 1 \mathrm{H}, \mathrm{J}=11.7 \mathrm{~Hz}), 3.76(\mathrm{~d}, 1 \mathrm{H}$ $\mathrm{J}=11.7 \mathrm{~Hz}) ;{ }^{13} \mathrm{C} \mathrm{NMR}\left(\mathrm{CDCl}_{3}\right) \delta 190.4,137.6,136.9,136.7(2$ C), 128.5-127.6 (20 C), 93.9, 87.5, 85.1, 83.6, 82.8, 73.8 (2 C), 73.0, 72.4, 67.7. Anal. Calcd for $\mathrm{C}_{35} \mathrm{H}_{34} \mathrm{O}_{6} \mathrm{~S}: \mathrm{C}, 72.14 ; \mathrm{H}, 5.88$. Found: $\mathrm{C}, 72.54 ; \mathrm{H}, 6.01$. 15: white solid. $\mathrm{R}_{\mathrm{f}}=0.28$ (EtOAd hexane 1:4); $\mathrm{mp} 79-81^{\circ} \mathrm{C} ;[\alpha]^{22} \mathrm{D}+46.8\left(\mathrm{c} 1.0, \mathrm{CHCl}_{3}\right) ;{ }^{1} \mathrm{H}$ NMR $\left(\mathrm{CDCl}_{3}\right) \delta 7.38-7.26(\mathrm{~m}, 18 \mathrm{H}), 7.22-7.19(\mathrm{~m}, 2 \mathrm{H}), 4.91(\mathrm{~d}, 1 \mathrm{H}$, $J=5.4 \mathrm{~Hz}), 4.82(\mathrm{~d}, 1 \mathrm{H}, \mathrm{J}=11.5 \mathrm{~Hz}), 4.76(\mathrm{~d}, 1 \mathrm{H}, \mathrm{J}=11.7$ $\mathrm{Hz}), 4.72(\mathrm{~d}, 1 \mathrm{H}, \mathrm{J}=12.0 \mathrm{~Hz}), 4.71(\mathrm{~d}, 1 \mathrm{H}, \mathrm{J}=11.5 \mathrm{~Hz}), 4.65$ $(\mathrm{d}, 1 \mathrm{H}, \mathrm{J}=12.0 \mathrm{~Hz}), 4.55(\mathrm{~d}, 1 \mathrm{H}, \mathrm{J}=11.7 \mathrm{~Hz}), 4.45(\mathrm{~d}, 1 \mathrm{H}, \mathrm{J}$ $=11.8 \mathrm{~Hz}), 4.38(\mathrm{~d}, 1 \mathrm{H}, \mathrm{J}=11.8 \mathrm{~Hz}), 4.21(\mathrm{t}, 1 \mathrm{H}, \mathrm{J}=8.8 \mathrm{~Hz})$, $3.86(\mathrm{~d}, 1 \mathrm{H}, \mathrm{J}=8.7 \mathrm{~Hz}), 3.79(\mathrm{dd}, 1 \mathrm{H}, \mathrm{J}=8.8,8.7 \mathrm{~Hz}), 3.55$ $(\mathrm{d}, 1 \mathrm{H}, \mathrm{J}=10.1 \mathrm{~Hz}), 3.43(\mathrm{~d}, 1 \mathrm{H}, \mathrm{J}=10.1 \mathrm{~Hz}) ;{ }^{13} \mathrm{C} \mathrm{NMR}$ $\left(\mathrm{CDCl}_{3}\right) \delta 190.6,137.9,137.3,137.0,136.6,128.6-127.7(20$ C), 91.2, 84.5, 81.9, 79.1, 78.3, 73.7, 73.6, 73.3, 72.3, 68.4. Anal. Calcd for $\mathrm{C}_{35} \mathrm{H}_{34} \mathrm{O}_{6} \mathrm{~S}$ : C, 72.14; $\mathrm{H}, 5.88$. Found: $\mathrm{C}, 72.20 ; \mathrm{H}$, 5.93.

[3S-(3 $\alpha, 4 \beta, 5 \alpha)]-3,4,5-T r i s(b e n z y l o x y)-1-(b e n z y l o x y m e-$ thyl)-1-cyclopentene (21). A solution of $14(280 \mathrm{mg}, 0.48$ $\mathrm{mmol})$ in (EtO) ${ }_{3} \mathrm{P}(5 \mathrm{~mL})$ was heated at $155^{\circ} \mathrm{C}$ for $2 \mathrm{~h}$. The solvent was removed at reduced pressure and the residue was purified by flash column chromatography (EtOAc/hexane 1:10) to afford 21 (226 mg, 93\%) as a colorless oil. Following this procedure, compound $\mathbf{1 5}$ afforded $\mathbf{2 1}$ in similar yield: $\mathrm{R}_{\mathrm{f}}=0.50$ (EtOAc/hexane 1:3); $[\alpha]^{22} \mathrm{D}+37.5$ (c 1.7, $\mathrm{CHCl}_{3}$ ); ${ }^{1 \mathrm{H}} \mathrm{NMR}$ $\left(\mathrm{CDCl}_{3}\right) \delta 7.42-7.31(\mathrm{~m}, 2 \mathrm{H}), 5.98-5.97(\mathrm{~m}, 1 \mathrm{H}), 4.73(\mathrm{~d}, 1 \mathrm{H}$, $\mathrm{J}=11.7 \mathrm{~Hz}), 4.71(\mathrm{~d}, 1 \mathrm{H}, \mathrm{J}=9.4 \mathrm{~Hz}), 4.67(\mathrm{~d}, 1 \mathrm{H}, \mathrm{J}=9.1$ $\mathrm{Hz}), 4.66(\mathrm{~d}, 1 \mathrm{H}, \mathrm{J}=11.8 \mathrm{~Hz}), 4.64(\mathrm{~d}, 1 \mathrm{H}, \mathrm{J}=9.5 \mathrm{~Hz}), 4.62$ $(\mathrm{d}, 1 \mathrm{H}, \mathrm{J}=11.8 \mathrm{~Hz}), 4.61(\mathrm{~d}, 1 \mathrm{H}, \mathrm{J}=11.8 \mathrm{~Hz}), 4.24(\mathrm{~d}, 1 \mathrm{H}, \mathrm{J}$ $=11.8 \mathrm{~Hz}), 4.54-4.53(\mathrm{~m}, 1 \mathrm{H}), 4.30(\mathrm{t}, 1 \mathrm{H}, \mathrm{J}=3.8 \mathrm{~Hz}), 4.19-$ $4.18(\mathrm{~m}, 1 \mathrm{H}) ;{ }^{13} \mathrm{C} \mathrm{NMR}\left(\mathrm{CDCl}_{3}\right) \delta 143.2,138.4,138.3,138.1$, 138.0, 128.3-127.2 (21 C), 91.4, 85.5, 85.2, 72.6, 71.9, 71.6, 70.8, 66.5. Anal. Calcd for $\mathrm{C}_{34} \mathrm{H}_{34} \mathrm{O}_{4}:$ C, 80.60; $\mathrm{H}, 6.76$. Found: C, 80.74; H, 6.94

Synthesis of Thionocarbonate 23 by Acetolysis of 14. To a solution of 14 (30 mg, $0.05 \mathrm{mmol}$ ) in acetic anhydride $(0.5 \mathrm{~mL})$ was added TMSOTf $(27 \mu \mathrm{L}, 0.15 \mathrm{mmol})$. After stirring for $17 \mathrm{~h}$ at room temperature, the mixture was diluted with $\mathrm{CH}_{2} \mathrm{Cl}_{2}(2 \mathrm{~mL})$, and aqueous saturated $\mathrm{NaHCO}_{3}(2 \mathrm{~mL})$ was cautiously added. After stirring for $30 \mathrm{~min}$, the aqueous layer was extracted with $\mathrm{CH}_{2} \mathrm{Cl}_{2}(3 \times 5 \mathrm{~mL})$, and the combined organic phases were dried over $\mathrm{Na}_{2} \mathrm{SO}_{4}$ and concentrated at reduced pressure. The residue was purified by flash column chromatography $\left(\mathrm{CH}_{2} \mathrm{Cl}_{2} /\right.$ hexane 1:1), affording unreacted 14 (12 mg) and 23 (17 mg, 58\%; 88\% based on recovered 14). 23 crystallized from ether/hexane as a white solid: $R_{f}=0.52$ (EtOAc/hexane 1:3); $\mathrm{mp} 72-73{ }^{\circ} \mathrm{C} ;[\alpha]^{22} \mathrm{D}+4.89$ (c 0.9, $\mathrm{CHCl}_{3}$ ); ${ }^{1} \mathrm{H}$ NMR $\left(\mathrm{CDCl}_{3}\right) \delta 7.39-7.28(\mathrm{~m}, 15 \mathrm{H}), 4.96(\mathrm{~d}, 1 \mathrm{H}, \mathrm{J}=4.1$ $\mathrm{Hz}), 4.78-4.60(\mathrm{~m}, 6 \mathrm{H}), 4.59(\mathrm{~d}, 1 \mathrm{H}, \mathrm{J}=13.2 \mathrm{~Hz}), 4.36(\mathrm{~d}, 1 \mathrm{H}$, 
$\mathrm{J}=13.2 \mathrm{~Hz}), 4.25(\mathrm{~d}, 1 \mathrm{H}, \mathrm{J}=7.5 \mathrm{~Hz}), 4.11(\mathrm{dd}, 1 \mathrm{H}, \mathrm{J}=7.0$, $4.1 \mathrm{~Hz}), 3.98(\mathrm{dd}, 1 \mathrm{H}, \mathrm{J}=7.5,7.0 \mathrm{~Hz}), 2.11(\mathrm{~s}, 3 \mathrm{H}) ;{ }^{13} \mathrm{C} N M R$ $\left(\mathrm{CDCl}_{3}\right) \delta 189.6,169.8,137.2,136.5,136.3,128.5-127.7$ (15 C), 93.0, 87.7, 84.7, 83.4, 82.4, 73.7, 72.9, 72.4, 62.2, 20.4. Anal. Calcd for $\mathrm{C}_{30} \mathrm{H}_{30} \mathrm{O}_{7} \mathrm{~S}$ : C, 67.40; $\mathrm{H}, 5.66$. Found: $\mathrm{C}, 67.65 ; \mathrm{H}$, 5.71.

Synthesis of Thionocarbonate 24 by Acetolysis of 15. Following the same procedure as for 23, compound 24 was obtained from 15 in $61 \%$ yield (89\% based on recovered 15$)$ as

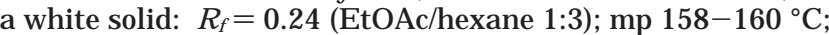
$[\alpha]^{22} \mathrm{D}+47.0\left(\mathrm{c} 0.6, \mathrm{CHCl}_{3}\right) ;{ }^{1} \mathrm{H}$ NMR $\left(\mathrm{CDCl}_{3}\right) \delta 7.36-7.29(\mathrm{~m}$, $15 \mathrm{H}), 4.89(\mathrm{~d}, 1 \mathrm{H}, \mathrm{J}=5.6 \mathrm{~Hz}), 4.81(\mathrm{~d}, 1 \mathrm{H}, \mathrm{J}=11.5 \mathrm{~Hz}), 4.78$ $(\mathrm{d}, 1 \mathrm{H}, \mathrm{J}=11.7 \mathrm{~Hz}), 4.73(\mathrm{~m}, 2 \mathrm{H}), 4.69(\mathrm{~d}, 1 \mathrm{H}, \mathrm{J}=11.5 \mathrm{~Hz})$, $4.54(\mathrm{~d}, 1 \mathrm{H}, \mathrm{J}=11.7 \mathrm{~Hz}), 4.30(\mathrm{~d}, 1 \mathrm{H}, \mathrm{J}=12.4 \mathrm{~Hz}), 4.22(\mathrm{~d}$, $1 \mathrm{H}, \mathrm{J}=8.3 \mathrm{~Hz}), 4.04(\mathrm{~d}, 1 \mathrm{H}, \mathrm{J}=12.4 \mathrm{~Hz}), 3.82(\mathrm{dd}, 1 \mathrm{H}, \mathrm{J}=$ 8.3, $5.6 \mathrm{~Hz}), 3.73(\mathrm{~d}, 1 \mathrm{H}, \mathrm{J}=8.3 \mathrm{~Hz}), 2.03(\mathrm{~s}, 3 \mathrm{H}) ;{ }^{13} \mathrm{C}$ NMR $\left(\mathrm{CDCl}_{3}\right) \delta 190.0,169.3,137.4,136.64,136.57,128.3-127.2(15$ C), 90.7, 84.0, 81.0, 78.5, 78.2, 73.0, 72.9, 71.9, 62.5, 19.9. Anal. Calcd for $\mathrm{C}_{30} \mathrm{H}_{30} \mathrm{O}_{7} \mathrm{~S}$ : $\mathrm{C}, 67.40 ; \mathrm{H}, 5.66$. Found: $\mathrm{C}, 67.02 ; \mathrm{H}$, 5.66.

[35-(3 $\alpha, 4 \beta, 5 \alpha)]-1-($ Acetoxymethyl)-3,4,5-tris(benzyloxy)1-cyclopentene (22). From 23. A solution of 23 (168 mg, $0.32 \mathrm{mmol})$ in (EtO) $)_{3} \mathrm{P}(3.2 \mathrm{~mL})$ was heated at $155^{\circ} \mathrm{C}$ for $3 \mathrm{~h}$. The solvent was removed at reduced pressure and the residue was purified by flash col umn chromatography (EtOAc/hexane 1:10) to afford 22 (140 mg, 97\%) as a colorless oil.

From 24. A solution of $\mathbf{2 4}(406 \mathrm{mg}, 0.76 \mathrm{mmol})$ in (EtO) $)_{3} \mathrm{P}$ $(7.7 \mathrm{~mL})$ was heated at $155^{\circ} \mathrm{C}$ for $2 \mathrm{~h}$. The solvent was removed at reduced pressure and the residue was purified by flash col umn chromatography (EtOAc/hexane 1:10) to afford 22 (342 mg, 98\%) as a colorless oil.

By Acetolysis of $\mathbf{2 1}$. To a solution of $\mathbf{2 1}(20 \mathrm{mg}, 0.04 \mathrm{mmol})$ in $\mathrm{Ac}_{2} \mathrm{O}(1 \mathrm{~mL})$ at $-60{ }^{\circ} \mathrm{C}$ was added TMSOTf $(8 \mu \mathrm{L}, 0.04$ $\mathrm{mmol}$ ). After stirring at $-60^{\circ} \mathrm{C}$ for $1 \mathrm{~h}$, the reaction mixture was diluted with $\mathrm{CH}_{2} \mathrm{Cl}_{2}(15 \mathrm{~mL})$ and aqueous saturated $\mathrm{NaHCO}_{3}$ was carefully added. The aqueous layer was extracted with $\mathrm{CH}_{2} \mathrm{Cl}_{2}(2 \times 30 \mathrm{~mL})$, and the combined organic extracts were dried over $\mathrm{Na}_{2} \mathrm{SO}_{4}$, filtered, and evaporated. The residue was coevaporated with toluene and purified by flash chromatography (EtOAc/hexane 1:10) to afford unreacted 21 (3 $\mathrm{mg}$ ) and $\mathbf{2 2}$ (9 $\mathrm{mg}, 50 \%$; 58\% based on recovered $\mathbf{2 1}$ ) as a colorless oil: 22: $R_{f}=0.31\left(E t O A c /\right.$ hexane 1:4); $[\alpha]^{22} \mathrm{D}+44.0$ (c 1.5, $\left.\mathrm{CHCl}_{3}\right) ;{ }^{1} \mathrm{H} \mathrm{NMR}\left(\mathrm{CDCl}_{3}\right) \delta 7.37-7.29(\mathrm{~m}, 15 \mathrm{H}), 5.90$ $(\mathrm{m}, 1 \mathrm{H}), 4.75-4.55(\mathrm{~m}, 8 \mathrm{H}), 4.75-4.45(\mathrm{~m}, 2 \mathrm{H}), 4.26(\mathrm{t}, 1 \mathrm{H}, \mathrm{J}$ $=3.8 \mathrm{~Hz}), 2.04(\mathrm{~s}, 3 \mathrm{H}) ;{ }^{13} \mathrm{C} \mathrm{NMR}\left(\mathrm{CDCl}_{3}\right) \delta 170.5,141.0,138.2$ (2 C), 138.1, 128.4-127.7 (16 C), 91.3, 85.4, 85.3, 72.0, 71.6, $71.0,60.5,20.8$.

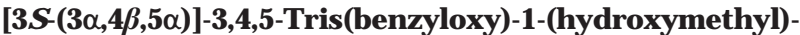
1-cyclopentene (25). A solution of $22(27 \mathrm{mg}, 0.06 \mathrm{mmol})$ in $\mathrm{CH}_{2} \mathrm{Cl}_{2} / \mathrm{MeOH}$ 1:1 (2 mL) was treated with a few drops of a freshly prepared solution of $\mathrm{NaOMe}$ in $\mathrm{MeOH}$. After stirring for $1 \mathrm{~h}$ at room temperature, Amberlite IR-120 ( $\mathrm{H}^{+}$type) was added and the reaction mixture was stirred for $10 \mathrm{~min}$. The mixture was filtered, the solvent was evaporated at reduced pressure, and the residue was purified by flash column chromatography (EtOAc/hexane 1:3) to afford 25 (24 mg, 96\%) as a white solid: $\mathrm{R}_{\mathrm{f}}=0.14$ (EtOAc/hexane $\left.1: 3\right) ; \mathrm{mp} 78-80{ }^{\circ} \mathrm{C}$; $[\alpha]^{22}{ }_{\mathrm{D}}+46.5\left(\mathrm{c} 1.5, \mathrm{CHCl}_{3}\right) ;{ }^{1} \mathrm{H} \mathrm{NMR}\left(\mathrm{CDCl}_{3}\right) \delta 7.36-7.28(\mathrm{~m}$, $15 \mathrm{H}), 5.87(\mathrm{~m}, 1 \mathrm{H}), 4.70(\mathrm{~d}, 1 \mathrm{H}, \mathrm{J}=11.6 \mathrm{~Hz}), 4.69(\mathrm{~d}, 1 \mathrm{H}, \mathrm{J}=$ $11.8 \mathrm{~Hz}), 4.63(\mathrm{~d}, 1 \mathrm{H}, \mathrm{J}=11.7 \mathrm{~Hz}), 4.63(\mathrm{~d}, 1 \mathrm{H}, \mathrm{J}=11.7 \mathrm{~Hz})$, $4.59(\mathrm{~d}, 1 \mathrm{H}, \mathrm{J}=11.7 \mathrm{~Hz}), 4.56(\mathrm{~d}, 1 \mathrm{H}, \mathrm{J}=11.7 \mathrm{~Hz}), 4.50(\mathrm{~m}$, $2 \mathrm{H}), 4.28(\mathrm{dd}, 1 \mathrm{H}, \mathrm{J}=14.1,4.6 \mathrm{~Hz}), 4.25(\mathrm{t}, 1 \mathrm{H}, \mathrm{J}=3.8 \mathrm{~Hz})$, $4.19(\mathrm{dd}, 1 \mathrm{H}, \mathrm{J}=14.1,7.1 \mathrm{~Hz}), 1.92(\mathrm{dd}, 1 \mathrm{H}, \mathrm{J}=7.1,4.6 \mathrm{~Hz})$; ${ }^{13} \mathrm{C}$ NMR $\left(\mathrm{CDCl}_{3}\right) \delta 145.1,138.3,138.1(2 \mathrm{C}), 128.4-127.8(15$ C), $126.2,91.6,86.0,85.5,72.0,71.8,71.0,60.3$. Anal. Calcd for $\mathrm{C}_{27} \mathrm{H}_{28} \mathrm{O}_{4}$ : C, 77.86; $\mathrm{H}, 6.78$. Found: $\mathrm{C}, 78.13 ; \mathrm{H}, 6.85$.

[1R-(1 $\alpha, 2 \alpha, 3 \beta, 4 \alpha, 5 \alpha)]-2,3,4-T r i s(b e n z y l o x y)-1-(h y d r o x y m-$ ethyl)-6-oxabicyclo[3.1.0]hexane (26). To a solution of diisopropyl L-tartrate $(235 \mathrm{mg}, 1.0 \mathrm{mmol})$ in $\mathrm{CH}_{2} \mathrm{Cl}_{2}(11 \mathrm{~mL})$ at $-30{ }^{\circ} \mathrm{C}$ was added $\mathrm{Ti}\left(\mathrm{O}^{\mathrm{P} P r}\right)_{4}(295 \mu \mathrm{L}, 1.0 \mathrm{mmol})$. After stirring for $20 \mathrm{~min}$ at $-30{ }^{\circ} \mathrm{C}$, a solution of 25 (287 mg, 0.69 $\mathrm{mmol}$ ) in $\mathrm{CH}_{2} \mathrm{Cl}_{2}(19 \mathrm{~mL}$ ) was added dropwise. After $20 \mathrm{~min}$, t-BuOOH (5.5 M in decane, $251 \mu \mathrm{L}, 1.38 \mathrm{mmol}$ ) was added and the stirring continued at $-30^{\circ} \mathrm{C}$ for $20 \mathrm{~h}$. The reaction mixture was diluted with $\mathrm{Et}_{2} \mathrm{O}(20 \mathrm{~mL})$ and a solution of $\mathrm{NaOH}$
$(3 \mathrm{~g})$ in brine $(30 \mathrm{~mL})$ was added. After stirring for $15 \mathrm{~min}$, the aqueous phase was extracted with $\mathrm{Et}_{2} \mathrm{O}(2 \times 20 \mathrm{~mL})$, and the combined organic phases were washed with brine. The aqueous brine layer was extracted with EtOAc $(2 \times 20 \mathrm{~mL})$, and the combined organic phases were dried over $\mathrm{MgSO}_{4}$ and concentrated at reduced pressure. The residue was purified by flash column chromatography (EtOAc/hexane 1:3) affording epoxide $\mathbf{2 6}$ ( $278 \mathrm{mg}, \mathbf{9 3 \%}$ ). $\mathbf{2 6}$ crystallized from $\mathrm{Et}_{2} \mathrm{O}$ as a white solid: $\mathrm{R}_{\mathrm{f}}=0.20$ (EtOAc/hexane $\left.1: 2\right) ; \mathrm{mp} 73-74{ }^{\circ} \mathrm{C} ;[\alpha]^{22} \mathrm{D}+25.9$ (c 1.0, $\left.\mathrm{CHCl}_{3}\right) ;{ }^{1} \mathrm{H} \mathrm{NMR}\left(\mathrm{CDCl}_{3}\right) \delta 7.37-7.27(\mathrm{~m}, 15 \mathrm{H}), 4.57$ $(\mathrm{d}, 1 \mathrm{H}, \mathrm{J}=12.0 \mathrm{~Hz}), 4.55(\mathrm{~s}, 2 \mathrm{H}), 4.46(\mathrm{~d}, 1 \mathrm{H}, \mathrm{J}=12.0 \mathrm{~Hz})$, $4.44(\mathrm{~d}, 1 \mathrm{H}, \mathrm{J}=12.3 \mathrm{~Hz}), 4.37(\mathrm{~d}, 1 \mathrm{H}, \mathrm{J}=12.3 \mathrm{~Hz}), 4.08(\mathrm{dd}$, $1 \mathrm{H}, \mathrm{J}=12.7,7.0 \mathrm{~Hz}), 3.99(\mathrm{t}, 1 \mathrm{H}, \mathrm{J}=1.2 \mathrm{~Hz}), 3.96(\mathrm{~d}, 1 \mathrm{H}, \mathrm{J}$ $=1.1 \mathrm{~Hz}), 3.95(\mathrm{~m}, 1 \mathrm{H}), 3.87(\mathrm{dd}, 1 \mathrm{H}, \mathrm{J}=12.7,6.2 \mathrm{~Hz}), 3.63$ $(\mathrm{s}, 1 \mathrm{H}), 1.85(\mathrm{t}, 1 \mathrm{H}, \mathrm{J}=6.7 \mathrm{~Hz}) ;{ }^{13} \mathrm{C} \mathrm{NMR}\left(\mathrm{CDCl}_{3}\right) \delta 137.6$ (3C), 128.4-127.8 (15 C), 89.7, 82.3, 82.0, 72.0 (2 C), 71.6, 68.4, 61.8, 59.5. Anal. Calcd for $\mathrm{C}_{27} \mathrm{H}_{28} \mathrm{O}_{5}$ : C, 74.98; $\mathrm{H}, 6.52$. Found: $\mathrm{C}, 74.86 ; \mathrm{H}, 6.44$.

[1S-(1 $\alpha, 2 \beta, 3 \alpha, 4 \beta, 5 \alpha)]-2,3,4-T r i s(b e n z y l o x y)-1-(h y d r o x y m-$ ethyl)-6-oxabicyclo[3.1.0]hexane (28). F ollowing the same procedure as for $\mathbf{2 6}$ but using diisopropyl D-tartrate, epoxide $\mathbf{2 8}$ was obtained from $\mathbf{2 5}$ in $\mathbf{8 6 \%}$ yield as a white solid. $\mathrm{R}_{\mathrm{f}}=$ 0.23 (EtOAc/hexane 1:1); $\mathrm{mp} 141-143{ }^{\circ} \mathrm{C} ;[\alpha]^{22} \mathrm{D}+41.3$ (c 0.5 , $\left.\mathrm{CHCl}_{3}\right) ;{ }^{1} \mathrm{H} N M R\left(\mathrm{C}_{6} \mathrm{D}_{6}\right) \delta$ 7.32-7.24 (m, 5H), 7.21-7.07 (m, $10 \mathrm{H}), 4.70(\mathrm{~d}, 1 \mathrm{H}, \mathrm{J}=11.8 \mathrm{~Hz}), 4.68(\mathrm{~d}, 1 \mathrm{H}, \mathrm{J}=12.0 \mathrm{~Hz})$, $4.56(\mathrm{~d}, 1 \mathrm{H}, \mathrm{J}=12.0 \mathrm{~Hz}), 4.53(\mathrm{~d}, 1 \mathrm{H}, \mathrm{J}=11.8 \mathrm{~Hz}), 4.52(\mathrm{~d}$, $1 \mathrm{H}, \mathrm{J}=12.0 \mathrm{~Hz}), 4.37(\mathrm{~d}, 1 \mathrm{H}, \mathrm{J}=12.0 \mathrm{~Hz}), 4.18(\mathrm{t}, 1 \mathrm{H}, \mathrm{J}=$ $5.8 \mathrm{~Hz}), 3.89(\mathrm{~d}, 1 \mathrm{H}, \mathrm{J}=5.8 \mathrm{~Hz}), 3.62(\mathrm{dd}, 1 \mathrm{H}, \mathrm{J}=5.8,1.3$ $\mathrm{Hz}), 3.58(\mathrm{~m}, 2 \mathrm{H}), 3.23(\mathrm{~d}, \mathrm{HH}, \mathrm{J}=1.3 \mathrm{~Hz}) ;{ }^{13} \mathrm{C} \mathrm{NMR}\left(\mathrm{CDCl}_{3}\right)$ $\delta 138.2,138.0,137.8,128.5-127.7$ (15 C) , 84.0, 81.5, 80.7, 72.5, 72.0, 71.3, 64.3, 59.3, 56.7. Anal. Calcd for $\mathrm{C}_{27} \mathrm{H}_{28} \mathrm{O}_{5}$ : C, 74.98; $\mathrm{H}, 6.52$. Found: $\mathrm{C}, 74.58 ; \mathrm{H}, 6.52$

[1R-(1 $\alpha, 2 \beta, 3 \alpha, 4 \beta, 5 \beta)]-5-A z i d o-2,3,4-t r i s(b e n z y l o x y)-1-$ (hydroxymethyl)-1-cyclopentanol (27). To a solution of $\mathbf{2 6}$ (50 $\mathrm{mg}, 0.11 \mathrm{mmol})$ in DMF $(2 \mathrm{~mL})$ were added lithium azide $\left(68 \mathrm{mg}, 1.39 \mathrm{mmol}\right.$ ) and $\mathrm{NH}_{4} \mathrm{Cl}(74 \mathrm{mg}, 1.39 \mathrm{mmol})$, and this mixture was stirred at $100{ }^{\circ} \mathrm{C}$ for 5 days. After disappearance of $\mathbf{2 6}$ (TLC toluene/acetone 8:1), DMF was evaporated at reduced pressure. The residue was dissolved in EtOAc $(10 \mathrm{~mL})$ and washed with water $(3 \mathrm{~mL})$, and the aqueous phase was extracted twice with EtOAc. The combined organic phases were dried over $\mathrm{Na}_{2} \mathrm{SO}_{4}$ and filtered, and the solvent was removed at reduced pressure. The residue was purified by flash column chromatography (EtOAc/hexane 1:3), affording azide 27 (48 mg, 89\%) as a colorless oil: $R_{f}=0.23$ (acetone/ toluene 1:8); $[\alpha]^{22} \mathrm{D}-12.0\left(\mathrm{c} \mathrm{0.6}, \mathrm{CHCl}_{3}\right)$; I $\mathrm{R}(\mathrm{KBr}) 3440,2100$, $1080 \mathrm{~cm}^{-1} ;{ }^{1} \mathrm{H}$ NMR $\left(\mathrm{C}_{6} \mathrm{D}_{6}\right) \delta 7.30-7.03(\mathrm{~m}, 15 \mathrm{H}), 4.49(\mathrm{~d}, 2 \mathrm{H}$, $\mathrm{J}=11.7 \mathrm{~Hz}), 4.42(\mathrm{~d}, 1 \mathrm{H}, \mathrm{J}=11.2 \mathrm{~Hz}), 4.39(\mathrm{~d}, 1 \mathrm{H}, \mathrm{J}=11.5$ $\mathrm{Hz}), 4.36(\mathrm{~d}, 1 \mathrm{H}, \mathrm{J}=11.8 \mathrm{~Hz}), 4.26(\mathrm{~d}, 1 \mathrm{H}, \mathrm{J}=11.7 \mathrm{~Hz}), 4.09$ $(\mathrm{t}, 1 \mathrm{H}, \mathrm{J}=5.2 \mathrm{~Hz}), 3.98(\mathrm{t}, 1 \mathrm{H}, \mathrm{J}=5.5 \mathrm{~Hz}), 3.92(\mathrm{~d}, 1 \mathrm{H}, \mathrm{J}=$ $11.7 \mathrm{~Hz}), 3.84(\mathrm{~d}, 1 \mathrm{H}, \mathrm{J}=5.8 \mathrm{~Hz}), 3.83(\mathrm{~d}, 1 \mathrm{H}, \mathrm{J}=11.7 \mathrm{~Hz})$, $3.58(\mathrm{dd}, 1 \mathrm{H}, \mathrm{J}=5.6,0.6 \mathrm{~Hz}), 3.20(\mathrm{br} \mathrm{s}, 1 \mathrm{H}) ;{ }^{13} \mathrm{C} \mathrm{NMR}\left(\mathrm{CDCl}_{3}\right)$ $\delta$ 137.7, 137.5, 137.4, 128.7-127.6 (15 C), 88.8, 87.0, 81.0, 80.1, 72.8 (2 C), 72.1, 66.1, 63.2.

[1S-(1 $\alpha, 2 \alpha, 3 \beta, 4 \alpha, 5 \beta)]-5-A z i d o-2,3,4-t r i s(b e n z y l o x y)-1-$ (hydroxymethyl)-1-cyclopentanol (29). To a solution of $\mathbf{2 8}$ ( $24 \mathrm{mg}, 0.055 \mathrm{mmol})$ in DMF ( $1 \mathrm{~mL}$ ) were added lithium azide (33 $\mathrm{mg}, 0.66 \mathrm{mmol}$ ) and $\mathrm{NH}_{4} \mathrm{Cl}(36 \mathrm{mg}, 0.66 \mathrm{mmol}$ ), and this mixture was stirred at $125^{\circ} \mathrm{C}$ overnight. DMF was evaporated at reduced pressure and the residue was dissolved in EtOAc $(10 \mathrm{~mL})$ and washed with water $(3 \mathrm{~mL})$, and the aqueous phase was extracted twice with EtOAc. The combined organic phases were dried over $\mathrm{Na}_{2} \mathrm{SO}_{4}$ and filtered, and the solvent was removed at reduced pressure. The residue was purified by flash column chromatography (EtOAc/hexane 1:3) affording azide 29 (24 mg, 92\%) as a white solid: $R_{f}=0.38$ (EtOAd

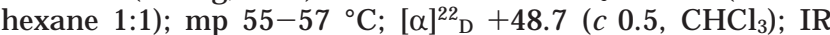
$\left(\mathrm{CHCl}_{3}\right) 3540,2120,1070,700 \mathrm{~cm}^{-1}$; ${ }^{1} \mathrm{H} \mathrm{NMR}\left(\mathrm{CDCl}_{3}\right) \delta 7.40$ $7.25(\mathrm{~m}, 15 \mathrm{H}), 4.71(\mathrm{~d}, 1 \mathrm{H}, \mathrm{J}=11.7 \mathrm{~Hz}), 4.71(\mathrm{~d}, 1 \mathrm{H}, \mathrm{J}=11.8$ $\mathrm{Hz}), 4.63(\mathrm{~d}, 1 \mathrm{H}, \mathrm{J}=11.7 \mathrm{~Hz}), 4.60(\mathrm{~d}, 1 \mathrm{H}, \mathrm{J}=11.8 \mathrm{~Hz}), 4.60$ $(\mathrm{d}, 1 \mathrm{H}, \mathrm{J}=11.7 \mathrm{~Hz}), 4.54(\mathrm{~d}, 1 \mathrm{H}, \mathrm{J}=11.7 \mathrm{~Hz}), 3.98(\mathrm{dd}, 1 \mathrm{H}$, $\mathrm{J}=5.6,4.2 \mathrm{~Hz}), 3.94(\mathrm{~d}, 1 \mathrm{H}, \mathrm{J}=7.4 \mathrm{~Hz}), 3.86(\mathrm{~d}, 1 \mathrm{H}, \mathrm{J}=4.2$ $\mathrm{Hz}), 3.74(\mathrm{dd}, 1 \mathrm{H}, \mathrm{J}=12.0,5.4 \mathrm{~Hz}), 3.73(\mathrm{ddd}, 1 \mathrm{H}, \mathrm{J}=7.4$, 5.6, 0.7 Hz), 3.50 (ddd, $1 \mathrm{H}, \mathrm{J}=12.0,8.0,0.7 \mathrm{~Hz}), 3.27(\mathrm{~s}, 1 \mathrm{H})$, $2.06(\mathrm{dd}, 1 \mathrm{H}, \mathrm{J}=8.0,5.4 \mathrm{~Hz}) ;{ }^{13} \mathrm{C} \mathrm{NMR}\left(\mathrm{CDCl}_{3}\right) \delta 137.7,137.5$, 
137.4, 128.7-127.6 (15 C), 88.8, 87.0, 81.0, 80.1, 72.8 (2 C), $72.1,66.1,63.2$.

[1R-(1 $\alpha, 2 \beta, 3 \alpha, 4 \beta, 5 \beta)]-5-A m i n o-1-(h y d r o x y m e t h y l)-1,2,3,4-$ cyclopentanetetrol (Trehazolamine) (3). To a solution of 27 (38 $\mathrm{mg}, 0.08 \mathrm{mmol}$ ) in $\mathrm{EtOH} / \mathrm{THF} 3: 1(4 \mathrm{~mL})$ were added TFA (31 $\mu \mathrm{L}, 0.40 \mathrm{mmol}$ ) and $25 \% \mathrm{Pd}(\mathrm{OH})_{2}$ on charcoal (135 $\mathrm{mg})$. This mixture was stirred under $\mathrm{H}_{2}(2 \mathrm{~atm})$ at room temperature overnight. The reaction mixture was filtered through Celite and the filter was washed with $\mathrm{MeOH}(4 \times 50$ $\mathrm{mL})$ and water $(50 \mathrm{~mL})$. The solvent was removed at reduced pressure and the residue was purified by column chromatography on Amberlite CG-50 ( $\mathrm{NH}_{4}{ }^{+}$type). Elution with $0.5 \mathrm{M}$ aqueous $\mathrm{NH}_{3}$ afforded $\mathbf{3}$ (10 mg, 67\%) as a white solid after freeze-drying: $\mathrm{R}_{\mathrm{f}}=0.53\left(\mathrm{CH}_{3} \mathrm{CN} / \mathrm{AcOH} / \mathrm{H}_{2} \mathrm{O} 6: 1: 3\right) ;[\alpha]^{22} \mathrm{D}+2.0$ (c $\left.0.6, \mathrm{H}_{2} \mathrm{O}\right) ;{ }^{1} \mathrm{H} N M R\left(\mathrm{D}_{2} \mathrm{O}\right) \delta 4.06(\mathrm{dd}, 1 \mathrm{H}$, J $=6.8,5.7 \mathrm{~Hz})$, $3.95(\mathrm{dd}, 1 \mathrm{H}, \mathrm{J}=6.6,5.7 \mathrm{~Hz}), 3.78(\mathrm{~d}, 1 \mathrm{H}, \mathrm{J}=6.6 \mathrm{~Hz}), 3.78$ $(\mathrm{d}, 1 \mathrm{H}, J=11.9 \mathrm{~Hz}), 3.72(\mathrm{~d}, 1 \mathrm{H}, \mathrm{J}=11.9 \mathrm{~Hz}), 3.25(\mathrm{~d}, 1 \mathrm{H}, \mathrm{J}$ $=6.8 \mathrm{~Hz}) ;{ }^{13} \mathrm{C} N M R\left(\mathrm{D}_{2} \mathrm{O}\right) \delta 82.2,81.9,79.7,73.7,61.9,58.5$.

[1S-(1 $\alpha, 2 \alpha, 3 \beta, 4 \alpha, 5 \beta)]-1-A m i n o-3,4,5-t r i s(b e n x y l o x y)-1-$ (benzyloxymethyl)-1-cyclopentanol (32). To a freshly prepared $0.1 \mathrm{M}$ solution of $\mathrm{Sml}_{2}$ in THF $(31 \mathrm{~mL}, 3.13 \mathrm{mmol}$ ) and $\mathrm{t}-\mathrm{BuOH}(250 \mu \mathrm{L}, 2.61 \mathrm{mmol})$ at $-30{ }^{\circ} \mathrm{C}$ was added dropwise a solution of $31^{16}$ (336 mg, $0.52 \mathrm{mmol}$ ) in THF (21 $\mathrm{mL}$ ). After stirring for $1 \mathrm{~h}$ at $-30^{\circ} \mathrm{C}$, the cooling bath was removed, the reaction mixture was allowed to attain room temperature. Water $(282 \mu \mathrm{L}, 15.66 \mathrm{mmol})$ was added and stirring continued for $1 \mathrm{~h}$. The reaction mixture was diluted with EtOAc $(50 \mathrm{~mL})$ and aqueous saturated $\mathrm{NaHCO}_{3}(100 \mathrm{~mL})$ was added. The phases were separated, and the aqueous phase was extracted with EtOAc $(3 \times 50 \mathrm{~mL})$. The combined organic extracts were washed with brine and dried over $\mathrm{Na}_{2-}$ $\mathrm{SO}_{4}$. The mixture was filtered and the solvent was removed at reduced pressure. The crude was purified by flash chromatography $\left(\mathrm{CH}_{2} \mathrm{Cl}_{2} / \mathrm{MeOH} 60: 1\right)$, affording 32 (250 mg, 88\%).
Amino alcohol 32 was recrystallized from i-PrOH as a white solid: $\mathrm{R}_{\mathrm{f}}=0.55\left(\mathrm{CH}_{2} \mathrm{Cl}_{2} / \mathrm{MeOH} 10: 1\right) ; \mathrm{mp} 105^{\circ} \mathrm{C} ;[\alpha]^{22} \mathrm{D}+3.6$ (c $\left.0.6, \mathrm{CHCl}_{3}\right) ;{ }^{1} \mathrm{H} \mathrm{NMR}\left(\mathrm{CDCl}_{3}\right) \delta 7.36-7.27(\mathrm{~m}, 2 \mathrm{H}), 4.72$ $(\mathrm{s}, 2 \mathrm{H}), 4.69(\mathrm{~d}, 1 \mathrm{H}, 11.6 \mathrm{~Hz}), 4.62(\mathrm{~d}, 1 \mathrm{H}, 11.6 \mathrm{~Hz}), 4.61(\mathrm{~s}$, $2 \mathrm{H}), 4.52(\mathrm{~s}, 2 \mathrm{H}), 4.02(\mathrm{dd}, 1 \mathrm{H}, \mathrm{J}=6.1,5.8 \mathrm{~Hz}), 3.94(\mathrm{~d}, 1 \mathrm{H}, \mathrm{J}$ $=5.8 \mathrm{~Hz}), 3.55(\mathrm{dd}, 1 \mathrm{H}, \mathrm{J}=7.9,6.1 \mathrm{~Hz}), 3.54(\mathrm{~d}, 1 \mathrm{H}, \mathrm{J}=9.8$ $\mathrm{Hz}), 3.47(\mathrm{~d}, 1 \mathrm{H}, \mathrm{J}=9.8 \mathrm{~Hz}), 3.27(\mathrm{~d}, 1 \mathrm{H}, \mathrm{J}=7.9 \mathrm{~Hz}), 3.00(\mathrm{br}$ s, $1 \mathrm{H}) ;{ }^{13} \mathrm{C} \mathrm{NMR}\left(\mathrm{CDCl}_{3}\right) \delta 138.4,138.2,137.8,137.7,128.3-$ $127.6(20 \mathrm{C}), 86.5(2 \mathrm{C}), 81.8,77.1,73.6,73.2,72.4,72.3,71.9$, 63.1.

[1S-(1 $\alpha, 2 \alpha, 3 \beta, 4 \alpha, 5 \beta)]-5-A m i n o-1-(h y d r o x y m e t h y l)-1,2,3,4-$ cyclopentanetetrol (30). Following the same procedure as for 3, its diastereoisomer $\mathbf{3 0}$ was obtained from $\mathbf{2 9}$ or $\mathbf{3 2}$ in $63 \%$ and $80 \%$ yield, respectively, as a white solid: $\mathrm{R}_{\mathrm{f}}=0.37$ $\left(\mathrm{CH}_{3} \mathrm{CN} / \mathrm{AcOH} / \mathrm{H}_{2} \mathrm{O} 6: 1: 3\right.$ ); $\mathrm{mp} 121-123^{\circ} \mathrm{C} ;[\alpha]^{22} \mathrm{D}+2.3$ (c 1.2, $\left.\mathrm{H}_{2} \mathrm{O}\right) ;{ }^{1} \mathrm{H} N M R\left(\mathrm{D}_{2} \mathrm{O}\right) \delta 3.81(\mathrm{dd}, 1 \mathrm{H}, \mathrm{J}=8.6,8.4 \mathrm{~Hz}), 3.66(\mathrm{~d}$, $1 \mathrm{H}, \mathrm{J}=8.6 \mathrm{~Hz}), 3.63(\mathrm{~s}, 2 \mathrm{H}), 3.53(\mathrm{dd}, 1 \mathrm{H}, \mathrm{J}=8.5,8.4 \mathrm{~Hz})$, $3.06(\mathrm{~d}, 1 \mathrm{H}, \mathrm{J}=8.5 \mathrm{~Hz}) ;{ }^{13} \mathrm{C} \mathrm{NMR}\left(\mathrm{D}_{2} \mathrm{O}\right) \delta 79.8,79.3,77.3$, 75.6, 64.7, 64.4.

Acknowledgment. This work was supported by grants PB-93-0127-C02-01 and PB-96-0833 from DGES, Ministerio de Educación y Cultura of Spain.

Supporting Information Available: Experimental procedures and characterization data for compounds $\mathbf{1 6 - 1 8}$, and ${ }^{1} \mathrm{H}$ NOE data for compounds $\mathbf{1 2}, \mathbf{1 3}$, and trans-diols $\mathbf{A}$ and $\mathbf{B}$ (3 pages). This material is contained in libraries on microfiche, immediately follows this article in the microfilm version of the journal, and can be ordered from the ACS; see any current masthead page for ordering information.

J O980831B 